\title{
Uniform $\mathrm{Sb}_{2} \mathrm{~S}_{3}$ optical coatings by chemical spray method
}

\author{
Jako S. Eensalu*, Atanas Katerski, Erki Kärber, Ilona Oja Acik, Arvo Mere \\ and Malle Krunks*
}

\author{
Full Research Paper \\ Address: \\ Laboratory of Thin Film Chemical Technologies, Department of \\ Materials and Environmental Technology, Tallinn University of \\ Technology, Ehitajate tee 5, Tallinn 19086, Estonia \\ Email: \\ Jako S. Eensalu* - jako.eensalu@taltech.ee; Malle Krunks ${ }^{*}$ - \\ malle.krunks@taltech.ee \\ * Corresponding author \\ Keywords: \\ antimony sulfide; thin films; ultrasonic spray; vacuum annealing; \\ Volmer-Weber growth
}

Beilstein J. Nanotechnol. 2019, 10, 198-210.

doi:10.3762/bjnano.10.18

Received: 22 September 2018

Accepted: 04 December 2018

Published: 15 January 2019

This article is part of the thematic issue "Chemical thin coating methods for functional nanomaterials".

Guest Editor: J. Bachmann

(C) 2019 Eensalu et al.; licensee Beilstein-Institut. License and terms: see end of document.

\begin{abstract}
Antimony sulfide $\left(\mathrm{Sb}_{2} \mathrm{~S}_{3}\right)$, an environmentally benign material, has been prepared by various deposition methods for use as a solar absorber due to its direct band gap of $\approx 1.7 \mathrm{eV}$ and high absorption coefficient in the visible light spectrum $\left(1.8 \times 10^{5} \mathrm{~cm}^{-1}\right.$ at $450 \mathrm{~nm}$ ). Rapid, scalable, economically viable and controllable in-air growth of continuous, uniform, polycrystalline $\mathrm{Sb}_{2} \mathrm{~S}_{3}$ absorber layers has not yet been accomplished. This could be achieved with chemical spray pyrolysis, a robust chemical method for deposition of thin films. We applied a two-stage process to produce continuous $\mathrm{Sb}_{2} \mathrm{~S}_{3}$ optical coatings with uniform thickness. First, amorphous $\mathrm{Sb}_{2} \mathrm{~S}_{3}$ layers, likely forming by 3D Volmer-Weber island growth through a molten phase reaction between $\mathrm{SbCl}_{3}$ and $\mathrm{SC}\left(\mathrm{NH}_{2}\right)_{2}$, were deposited in air on a glass $/ \mathrm{ITO} / \mathrm{TiO}_{2}$ substrate by ultrasonic spraying of methanolic $\mathrm{Sb} / \mathrm{S} 1: 3$ molar ratio solution at $200-210{ }^{\circ} \mathrm{C}$. Second, we produced polycrystalline uniform films of $\mathrm{Sb}_{2} \mathrm{~S}_{3}\left(E_{\mathrm{g}} 1.8 \mathrm{eV}\right)$ with a post-deposition thermal treatment of amorphous $\mathrm{Sb}_{2} \mathrm{~S}_{3}$ layers in vacuum at $170^{\circ} \mathrm{C},<4 \times 10^{-6}$ Torr for 5 minutes. The effects of the deposition temperature, the precursor molar ratio and the thermal treatment temperature on the $\mathrm{Sb}_{2} \mathrm{~S}_{3}$ layers were investigated using Raman spectroscopy, $\mathrm{X}$-ray diffraction, scanning electron microscopy, energy dispersive X-ray spectroscopy and UV-vis-NIR spectroscopy. We demonstrated that $\mathrm{Sb}_{2} \mathrm{~S}_{3}$ optical coatings with controllable structure, morphology and optical properties can be deposited by ultrasonic spray pyrolysis in air by tuning of the deposition temperature, the $\mathrm{Sb} / \mathrm{S}$ precursor molar ratio in the spray solution, and the postdeposition treatment temperature.
\end{abstract}

\section{Introduction}

Antimony sulfide $\left(\mathrm{Sb}_{2} \mathrm{~S}_{3}\right)$ is an environmentally benign material. As Sb and S are abundant elements in the Earth's crust, enough raw materials can be supplied to manufacture large quantities of $\mathrm{Sb}_{2} \mathrm{~S}_{3}$ in the long term. $\mathrm{Sb}_{2} \mathrm{~S}_{3}$ can be applied as the inorganic absorber in solar cells due to its direct band gap of $\approx 1.7 \mathrm{eV}[1,2]$. 
$\mathrm{Sb}_{2} \mathrm{~S}_{3}$, prepared by a chemical bath deposition (CBD) $[3,4]$, spin coating [5], atomic layer deposition (ALD) [6] or chemical spray pyrolysis (CSP) [7] method, has been applied in extremely thin absorber (ETA) solar cells due to its excellent absorption coefficient in the visible light spectrum $\left(1.8 \times 10^{5} \mathrm{~cm}^{-1}\right.$ at $450 \mathrm{~nm}$ ) [1,2]. Improvements in photocurrent density have been sought by utilizing a transparent, nanostructured window layer instead of planar window layers with the ETA $\mathrm{Sb}_{2} \mathrm{~S}_{3}$ absorber layer [4,7]. Previous studies show that achieving sufficient repeatability alongside optimization of the component layers, i.e., transparent (structured) window layer, $\mathrm{Sb}_{2} \mathrm{~S}_{3}$ absorber layer, and hole transport material layer, and their respective interfaces, is a tremendous undertaking [4].

Attention has surged toward planar heterojunction $\mathrm{Sb}_{2} \mathrm{~S}_{3}$ solar cells due to their simpler structure, less intricate production, and enhanced repeatability vs structured solar cells [8]. Planar $\approx 1.7 \mathrm{eV}$ absorber layers can be applied in semitransparent solar cells as well as in tandem solar cells.

Chemical spray pyrolysis (CSP) is a robust and industrially scalable chemical method for rapid deposition of thin films [9]. Our research group first investigated spray-deposited $\mathrm{Sb}_{2} \mathrm{~S}_{3}$ by pneumatically spraying aqueous solutions (tartaric acid added as complexing agent to prevent hydrolysis [10], akin to studies by Rajpure et al. [11]) or methanolic solutions of $\mathrm{SbCl}_{3}$. Following, we studied the effect of the $\mathrm{Sb} / \mathrm{S}$ precursor molar ratio in solution on ultrasonically sprayed $\mathrm{Sb}_{2} \mathrm{~S}_{3}$ layers and presented the first planar $\mathrm{TiO}_{2} / \mathrm{Sb}_{2} \mathrm{~S}_{3} / \mathrm{P} 3 \mathrm{HT}$ solar cells comprising ultrasonically sprayed $\mathrm{Sb}_{2} \mathrm{~S}_{3}$ (power conversion efficiency $\eta \leq 1.9 \%$ ) [12].

$\mathrm{SbCl}_{3}$ and thiourea $\left(\mathrm{SC}\left(\mathrm{NH}_{2}\right)_{2}\right)$ are often used in the field to deposit $\mathrm{Sb}_{2} \mathrm{~S}_{3}$ thin films. Spraying the $\mathrm{SbCl}_{3} / \mathrm{SC}\left(\mathrm{NH}_{2}\right)_{2}$ (henceforth $\mathrm{Sb} / \mathrm{S}$ ) 1:6 molar ratio solution at $250{ }^{\circ} \mathrm{C}$ in air yielded separate $\mathrm{Sb}_{2} \mathrm{~S}_{3}$ grains, which did not cover the $\mathrm{TiO}_{2}$ substrate entirely, whereas spraying the $\mathrm{Sb} / \mathrm{S} 1: 3$ solution yielded an inhomogeneous mix of amorphous and polycrystalline $\mathrm{Sb}_{2} \mathrm{~S}_{3}$ [12]. We learned to produce continuous uniform layers of polycrystalline $\mathrm{Sb}_{2} \mathrm{~S}_{3}$ by a two-step process on $\mathrm{ZnO}$ nanorod/ $/ \mathrm{TiO}_{2}$ substrates [7]. In this study, we applied this two-step process, i.e., depositing amorphous $\mathrm{Sb}_{2} \mathrm{~S}_{3}$ layers on planar substrates, followed by post-deposition crystallization.

The aim of this study was to produce crystalline, continuous, $\mathrm{Sb}_{2} \mathrm{~S}_{3}$ optical coatings with uniform thickness to be applied as a photovoltaic absorber by ultrasonic spraying on planar glass/ ITO/ $\mathrm{TiO}_{2}$ substrates, followed by a post-deposition treatment. To this end, we studied the effect of the deposition temperature $\left(T_{\mathrm{D}}\right)$, the molar ratio of precursors $\mathrm{SbCl}_{3}$ and thiourea $\left(\mathrm{SC}\left(\mathrm{NH}_{2}\right)_{2}\right)$ in the spray solution, and the post-deposition treat- ment temperature on the structure, morphology and optical properties of ultrasonically sprayed $\mathrm{Sb}_{2} \mathrm{~S}_{3}$ thin films.

\section{Results and Discussion}

Two sequential operations were used to obtain homogeneous $\mathrm{Sb}_{2} \mathrm{~S}_{3}$ optical coatings with uniform thickness on planar $\mathrm{TiO}_{2}$ substrates. First, we tuned the deposition temperature and molar ratio of $\mathrm{Sb} / \mathrm{S}$ precursors in spray solution to deposit continuous amorphous $\mathrm{Sb}_{2} \mathrm{~S}_{3}$ layers. An intimate contact, which is a prerequisite for high power conversion efficiency in solar cells [13], is formed at the interface between $\mathrm{TiO}_{2}$ and $\mathrm{Sb}_{2} \mathrm{~S}_{3}$ during deposition of amorphous $\mathrm{Sb}_{2} \mathrm{~S}_{3}$ layers. Second, all layers were thermally treated in an inert environment (vacuum, $<4 \times 10^{-6}$ Torr) to induce crystallization, without oxidation.

Preliminary experiments at deposition temperatures lower than $182{ }^{\circ} \mathrm{C}$ (decomposition of $\left.\mathrm{SC}\left(\mathrm{NH}_{2}\right)_{2}[14,15]\right)$ yielded inhomogeneous red-brown layers. Furthermore, in our previous paper, $250^{\circ} \mathrm{C}$ was found to be too high a deposition temperature to obtain sufficient coverage of $\mathrm{TiO}_{2}$ substrate by polycrystalline $\mathrm{Sb}_{2} \mathrm{~S}_{3}$ thin films, despite the suitable band gap of $1.6 \mathrm{eV}$ and high phase purity [12]. Restricted to deposition temperatures in the range $182-250{ }^{\circ} \mathrm{C}$, we sprayed $\mathrm{Sb} / \mathrm{S} 1: 3$ and 1:6 molar ratio precursor solutions at $T_{\mathrm{D}}=200,210$, and $220^{\circ} \mathrm{C}$. We varied the aforementioned parameters to attain the conditions to deposit dense and homogeneous layers of amorphous $\mathrm{Sb}_{2} \mathrm{~S}_{3}$, which we then crystallized by a post-deposition thermal treatment.

Based on the scanning electron microscopy (SEM) images, preliminary experiments revealed that spraying $\mathrm{Sb} / \mathrm{S} \mathrm{1:6}$ solutions consistently yielded twice thinner layers compared to layers deposited from $\mathrm{Sb} / \mathrm{S} \mathrm{1:3}$ solutions. $\mathrm{Sb}_{2} \mathrm{~S}_{3}$ layers of comparable thickness were deposited by spraying $\mathrm{Sb} / \mathrm{S}$ 1:6 solutions for 40 minutes and $\mathrm{Sb} / \mathrm{S} 1: 3$ solutions for 20 minutes.

The samples are named in the text as follows: A-B-C, where A is the $\mathrm{S} / \mathrm{Sb}$ molar ratio in solution, $\mathrm{B}$ is the deposition temperature, and $\mathrm{C}$ is the specification of the treatment. [ $\mathrm{Sb} / \mathrm{S}$ molar ratio in solution: "3" for $\mathrm{Sb} / \mathrm{S} \mathrm{1:3} \mathrm{or} \mathrm{"6"} \mathrm{for} \mathrm{Sb} / \mathrm{S} \mathrm{1:6]-[deposi-}$ tion temperature: "200", "210" or " 220 " $\left({ }^{\circ} \mathrm{C}\right)$ ]-[treatment: "Asdep." for as-deposited and " 170 ", “200" or " 250 " $\left({ }^{\circ} \mathrm{C}\right)$ for samples thermally treated in vacuum].

The samples in which $\mathrm{Sb}_{2} \mathrm{~S}_{3}$ layers were deposited from either $\mathrm{Sb} / \mathrm{S} 1: 3$ or $1: 6$ solution at $T_{\mathrm{D}}=200{ }^{\circ} \mathrm{C}$, followed by thermal treatment in vacuum at $200{ }^{\circ} \mathrm{C}(3-200-200,6-200-200)$, contain no $\mathrm{Sb}_{2} \mathrm{~S}_{3}$, as it likely volatilized completely during the vacuum thermal treatment. Likewise, treating the $\mathrm{Sb}_{2} \mathrm{~S}_{3}$ layers at temperatures higher than $200{ }^{\circ} \mathrm{C}$ caused $\mathrm{Sb}_{2} \mathrm{~S}_{3}$ to completely volatilize during treatment. Photographs of the samples (Figure S1) and the description of the vapor pressure calculations 
(Comment S1) are provided in the Supporting Information File 1. Consequently, only as-deposited samples and samples thermally treated in vacuum at $170{ }^{\circ} \mathrm{C}$ and $200{ }^{\circ} \mathrm{C}$ are eligible for discussion.

\section{Structure of as-deposited and thermally treated $\mathrm{Sb}_{2} \mathrm{~S}_{3}$ layers}

Raman spectroscopy provides quantitative and qualitative information on the vibrational modes in solids. The wide Raman band centered at $290 \mathrm{~cm}^{-1}[12,16]$ associated with metastibnite, i.e., amorphous $\mathrm{Sb}_{2} \mathrm{~S}_{3}$, is characteristic of as-deposited orange colored (photograph in Supporting Information File 1, Figure S1) samples (3-200-As-dep., 3-210-As-dep., Figure 1A; 6-200As-dep., Figure 1B). The band centered at $145 \mathrm{~cm}^{-1}$ is a low frequency $E_{\mathrm{g}}$ vibrational mode of anatase- $\mathrm{TiO}_{2}$ [17], which is observed due to the laser beam penetrating to the substrate $[12,16]$ through the discontinuous $\mathrm{Sb}_{2} \mathrm{~S}_{3}$ layers. The $\mathrm{TiO}_{2}$ vibrational band is absent in spectra of $\mathrm{Sb}_{2} \mathrm{~S}_{3}$ layers containing less pinholes, as the signal is captured only from $\mathrm{Sb}_{2} \mathrm{~S}_{3}$.

The narrower bands, attributed to orthorhombic $\mathrm{Sb}_{2} \mathrm{~S}_{3}[16,18$ $20]$, are present in the spectra of as-deposited and thermally treated lustrous gray (photograph in Supporting Information File 1, Figure S1) samples (3-200-170, 3-210-170, 3-210-200, 3-220-As-dep., 3-220-170, 3-220-200, Figure 1A; 6-200-170, 6-210-As-dep., 6-210-170, 6-210-200, 6-220-As-dep., 6-220170, 6-220-200, Figure 1B; photograph in Supporting Information File 1, Figure S1). According to group theory, orthorhombic $\mathrm{Sb}_{2} \mathrm{~S}_{3}$ has 30 predicted Raman active modes: $\Gamma_{\text {Raman }}=10 A_{\mathrm{g}}+5 B_{1 \mathrm{~g}}+10 B_{2 \mathrm{~g}}+5 B_{3 \mathrm{~g}}[18,20]$. The Raman spectra were deconvoluted using Lorentzian fitting into vibrational bands of $\mathrm{Sb}_{2} \mathrm{~S}_{3}$ based on the literature [12,16,21,22]. The centers of the bands of $\mathrm{Sb}_{2} \mathrm{~S}_{3}$ in the deconvoluted Raman spectra (Table 1, symmetries taken from $[20,21]$ ) are similar to
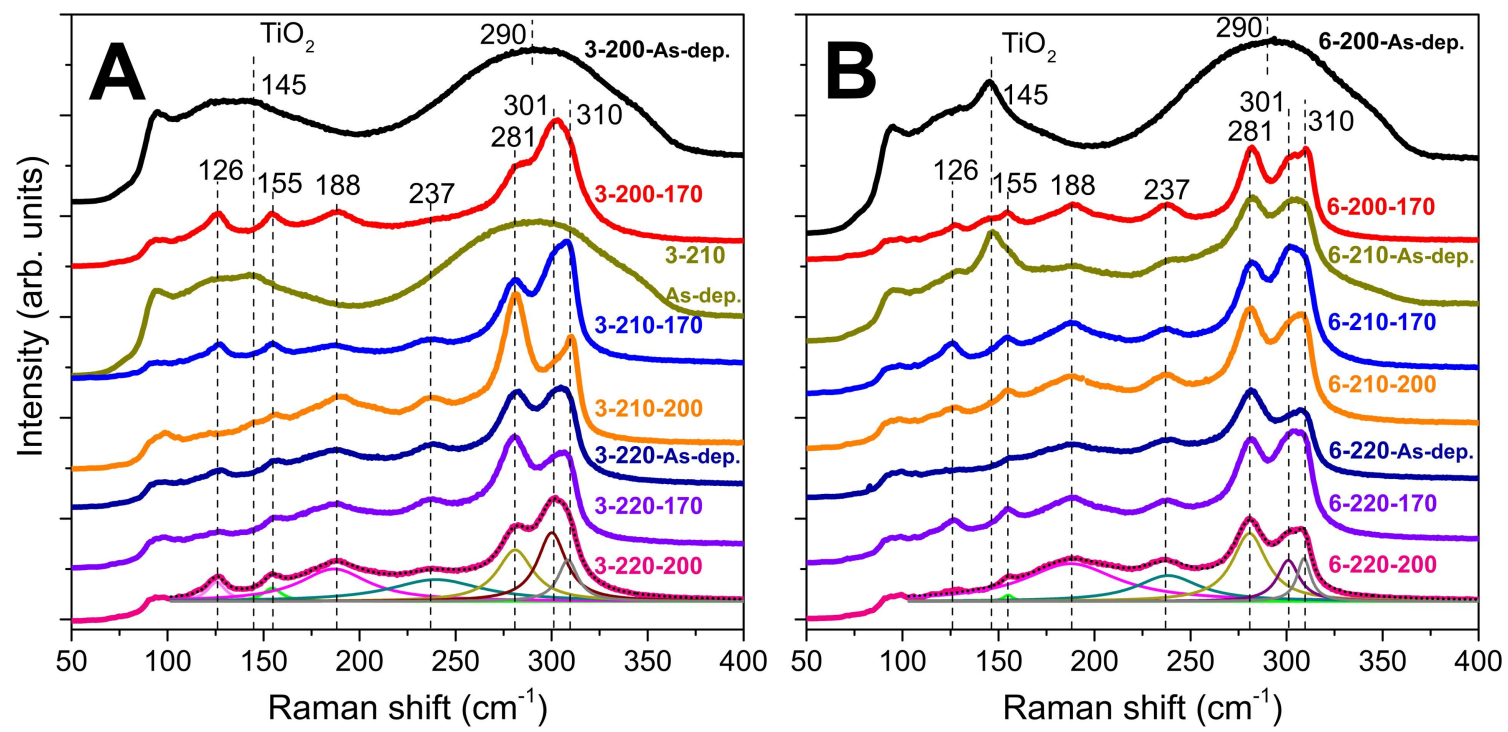

Figure 1: Raman spectra (shifted for visibility) of the as-deposited and thermally treated $\mathrm{Sb}_{2} \mathrm{~S}_{3}$ films deposited from $\mathrm{Sb} / \mathrm{S} 1: 3$ (A) or 1:6 (B) solution at $200,210,220^{\circ} \mathrm{C}$. Examples of deconvoluted fitted band curves are presented for the lowermost spectra. Sample names in figures: [S/Sb molar ratio in solution]-[deposition temperature]-[thermal treatment temperature].

Table 1: Raman band centers and assigned active modes for the studied $\mathrm{Sb}_{2} \mathrm{~S}_{3}$ layers.

\begin{tabular}{|c|c|c|c|c|c|}
\hline \multicolumn{3}{|c|}{ Center of Raman band, $\mathrm{cm}^{-1}$} & \multicolumn{2}{|c|}{ Symmetry } & \multirow[t]{2}{*}{ Vibrational mode, [21-23] } \\
\hline This study & Ref. [21] & Ref. [20] & Ref. [21] & Ref. [20] & \\
\hline 126 & 125 & 129 & $A_{\mathrm{g}}$ & $A_{\mathrm{g}}$ & lattice mode \\
\hline 155 & 156 & 158 & $A_{\mathrm{g}}$ & $A_{\mathrm{g}} / B_{2 \mathrm{~g}}$ & lattice mode \\
\hline 188 & 189 & 186 & $B_{1 \mathrm{~g}}$ & $B_{1 \mathrm{~g}}$ & antisym. S-Sb-S bending \\
\hline 237 & 237 & 239 & $B_{1 \mathrm{~g}}$ & $B_{1 g} / B_{3 g}$ & symmetric $\mathrm{S}-\mathrm{Sb}-\mathrm{S}$ bending \\
\hline 281 & 281 & 282 & $A_{\mathrm{g}}$ & $A_{\mathrm{g}} / B_{2 \mathrm{~g}}$ & antisym. S-Sb-S stretching \\
\hline 301 & 300 & 299 & $A_{\mathrm{g}}$ & $A_{\mathrm{g}} / B_{2 \mathrm{~g}}$ & antisym. S-Sb-S stretching \\
\hline 310 & 310 & 312 & $A_{\mathrm{g}}$ & $A_{\mathrm{g}} / B_{2 \mathrm{~g}}$ & symmetric S-Sb-S stretching \\
\hline
\end{tabular}


values reported in our previous studies $[7,12]$. Band centers, relative single peak intensities and full widths at half maximum (FWHM) of the narrow bands centered at 281, 301 and $310 \mathrm{~cm}^{-1}$ can be respectively found in Tables S1, S2, and S3 of Supporting Information File 1.

The FWHM of the vibrational band centered at $281 \mathrm{~cm}^{-1}$ narrows from $\approx 24 \mathrm{~cm}^{-1}$ to $21-23 \mathrm{~cm}^{-1}$ after vacuum thermal treatment of the samples deposited at $210-220{ }^{\circ} \mathrm{C}$ from both $\mathrm{Sb} / \mathrm{S} \mathrm{1:3}$ and $\mathrm{Sb} / \mathrm{S} \mathrm{1:6}$ solutions (3-210-170, 3-220-170, 6-210170 and 6-220-170) at $170{ }^{\circ} \mathrm{C}(3-210-170,3-220-170,6-210-$ 170 and 6-220-170) and narrows by $5 \mathrm{~cm}^{-1}$ at most after vacuum thermal treatment at $200{ }^{\circ} \mathrm{C}(3-210-200)$. The narrowing of the Raman bands due to thermal treatment leads us to suppose that crystallization continues during the vacuum thermal treatment and proceeds further at higher thermal treatment temperatures [16]. The vibrational bands corresponding to $\mathrm{Sb}_{2} \mathrm{O}_{3}$ were not detected by Raman spectroscopy in any of the studied glass/ITO/ $/ \mathrm{TiO}_{2} / \mathrm{Sb}_{2} \mathrm{~S}_{3}$ samples.
$\mathrm{X}$-ray diffraction (XRD) provides qualitative information on the phase composition and crystal structure. XRD patterns of reference glass/ITO/TiO 2 samples and samples containing XRDamorphous $\mathrm{Sb}_{2} \mathrm{~S}_{3}$ (3-200-As-dep., 3-210-As-dep., Figure 2A; 6-200-As-dep., Figure 2B) show only diffraction peaks corresponding to cubic $\operatorname{In}_{2} \mathrm{O}_{3}\left(2 \theta=21.3^{\circ}, 30.4^{\circ}, 35.3^{\circ}, 37.4^{\circ}, 41.4^{\circ}\right.$, $45.3^{\circ}$, ICDD PDF 03-065-3170) and anatase- $\mathrm{TiO}_{2}\left(25.3^{\circ}\right.$, 48.2 , ICDD PDF 00-016-0617). The diffraction peaks of orthorhombic $\mathrm{Sb}_{2} \mathrm{~S}_{3}$ (ICDD PDF 01-075-4012), space group Pnma $\left(D_{2 \mathrm{~h}}{ }^{16}\right)[20,24,25]$, appear in XRD patterns of lustrous gray as-deposited and thermally treated $\mathrm{Sb}_{2} \mathrm{~S}_{3}$ samples (3-200170, 3-210-170, 3-210-200, 3-220-As-dep., 3-220-170, 3-220200, Figure 2A; 6-200-170, 6-210-As-dep., 6-210-170, 6-210200, 6-220-As-dep., 6-220-170, 6-220-200, Figure 2B). The $2 \theta$ angles of observed $\mathrm{Sb}_{2} \mathrm{~S}_{3}$ diffraction peaks and corresponding crystal plane indices are presented in Supporting Information File 1, Table S4. Experimentally determined mean lattice constants $a, b$ and $c$ of $\mathrm{Sb}_{2} \mathrm{~S}_{3}$ are $11.25 \pm 0.07 \AA, 3.810 \pm 0.025 \AA$ and $11.16 \pm 0.07 \AA$, respectively. Our experimentally deter-
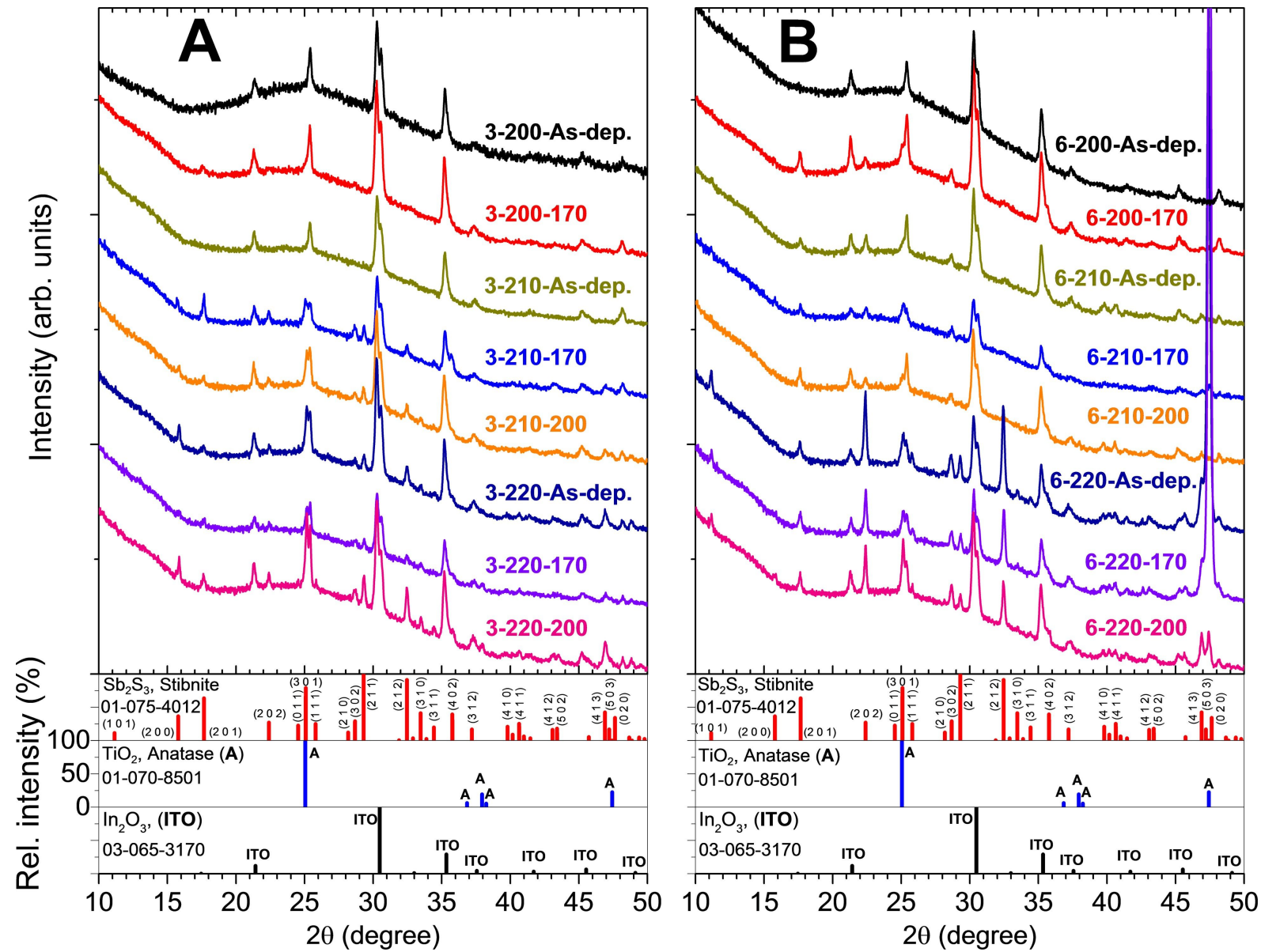

Figure 2: XRD patterns (shifted for visibility) of as-deposited and vacuum treated $\left(170{ }^{\circ} \mathrm{C}\right.$ or $200{ }^{\circ} \mathrm{C}, 5$ minutes) $\mathrm{Sb}_{2} \mathrm{~S}_{3}$ layers deposited on glass/ITO/ $\mathrm{TiO}_{2}$ substrate from Sb/S 1:3 (A) or 1:6 (B) solution at $T_{\mathrm{S}}=200,210,220^{\circ} \mathrm{C}$. Sample names in figures: [S/Sb molar ratio in solution]-[deposition temperature]-[thermal treatment temperature]. 
mined mean unit cell volume $\left(479 \pm 4 \AA^{3}\right)$ lies between the experimentally determined volume $\left(486.7 \AA^{3}\right)$ and the theoretically determined volume $\left(470.5 \AA^{3}\right)$ calculated from orthorhombic $\mathrm{Sb}_{2} \mathrm{~S}_{3}$ powder ( $>99.99 \mathrm{wt} \%$ ) data presented by Ibáñez et al. [20].

$\mathrm{Sb}_{2} \mathrm{~S}_{3}$ layers deposited from $\mathrm{Sb} / \mathrm{S}$ 1:6 solution at $210^{\circ} \mathrm{C}(6-210$ As-dep., Figure 2B) are polycrystalline, whereas layers deposited from $\mathrm{Sb} / \mathrm{S}$ 1:3 solution (3-210-As-dep., Figure 2A) are XRD-amorphous. $\mathrm{Sb}_{2} \mathrm{~S}_{3}$ layers deposited at $220{ }^{\circ} \mathrm{C}$ from both Sb/S 1:3 (3-220-As-dep., Figure 2A) and 1:6 (6-220-Asdep., Figure 2B) solution are polycrystalline. Several diffraction peaks corresponding to orthorhombic $\mathrm{Sb}_{2} \mathrm{~S}_{3}$ were detected in these samples. No additional phases were detected by XRD in any studied samples. The presence or absence of amorphous $\mathrm{Sb}_{2} \mathrm{O}_{3}$ as a minor phase in the $\mathrm{Sb}_{2} \mathrm{~S}_{3}$ layers, as it is difficult to ascertain by Raman or XRD analyses, has not been conclusively demonstrated.

The diffraction peak of the $\left(\begin{array}{lll}2 & 0 & 0\end{array}\right) /\left(\begin{array}{lll}0 & 0 & 2\end{array}\right)$ plane of $\mathrm{Sb}_{2} \mathrm{~S}_{3}$ is absent in most samples deposited from $\mathrm{Sb} / \mathrm{S}$ 1:6 solution. Conversely, the diffraction peak of the (llll $\left.\begin{array}{lll}1 & 0 & 1\end{array}\right)$ plane of $\mathrm{Sb}_{2} \mathrm{~S}_{3}$ is absent in all samples deposited from $\mathrm{Sb} / \mathrm{S}$ 1:3 solution. $\mathrm{Sb}_{2} \mathrm{~S}_{3}$ crystallites in most of our samples have no preferred orientation. Only crystallites in as-deposited and vacuum treated $\left(170{ }^{\circ} \mathrm{C}\right)$ samples deposited from $\mathrm{Sb} / \mathrm{S}$ 1:6 solution (6-220-Asdep., 6-220-170, Figure 2B) show a preferred orientation parallel to the substrate surface along the $\left(\begin{array}{lll}0 & 2 & 0\end{array}\right)$ plane normal of $\mathrm{Sb}_{2} \mathrm{~S}_{3}$. Interestingly, this preferred orientation of crystallites does not extend to the sample with $\mathrm{Sb}_{2} \mathrm{~S}_{3}$ deposited in the same conditions, but thermally treated in vacuum at $200{ }^{\circ} \mathrm{C}(6-220$ 200, Figure 2B).

The larger crystallite size is a boon to the power conversion efficiency of all solar absorber materials because decreasing the amount of grain boundaries likely increases charge carrier mobility [26]. The crystallite sizes of as-deposited and thermally treated $\mathrm{Sb}_{2} \mathrm{~S}_{3}$ layers are presented in Table 2. The effect of the deposition temperature is observed in $\mathrm{Sb} / \mathrm{S} 1: 3 \mathrm{Sb}_{2} \mathrm{~S}_{3}$ layers, as the crystallite size increases after vacuum annealing at $170{ }^{\circ} \mathrm{C}$ from $19 \pm 8 \mathrm{~nm}$ to $100 \pm 23 \mathrm{~nm}$ by raising $T_{\mathrm{D}}$ from 200 to $220^{\circ} \mathrm{C}$. The crystallite size in $\mathrm{Sb} / \mathrm{S} 1: 6 \mathrm{Sb}_{2} \mathrm{~S}_{3}$ layers (42 $\pm 15 \mathrm{~nm}$ ) does not change significantly with $T_{\mathrm{D}}$ or vacuum treatment. Furthermore, vacuum treatment at $200{ }^{\circ} \mathrm{C}$ vs $170{ }^{\circ} \mathrm{C}$ does not substantially affect the crystallite size of $\mathrm{Sb}_{2} \mathrm{~S}_{3}$ layers.

In comparison, the largest crystallites in $\mathrm{Sb}_{2} \mathrm{~S}_{3}$ layers grown on $\mathrm{TiO}_{2}$ substrates via $\mathrm{CBD}$ and annealed at $270{ }^{\circ} \mathrm{C}$ in $\mathrm{N}_{2}$ for 30 min oriented along the $(200)$ plane parallel to the substrate were $74 \mathrm{~nm}$ in size [16]. The crystallites oriented along the ( $\left.\begin{array}{lll}2 & 0 & 1\end{array}\right)$ plane were $24 \mathrm{~nm}$ in size in $\mathrm{Sb}_{2} \mathrm{~S}_{3}$ layers grown on $\mathrm{SnO}_{2} / \mathrm{F}$ (FTO) coated glass substrates via thermal evaporation [27]. The crystallite size was $52 \mathrm{~nm}$ along the (3 011$)$ plane in $\mathrm{Sb}_{2} \mathrm{~S}_{3}$ layers grown on glass substrates at $250^{\circ} \mathrm{C}$ via spray pyrolysis [28], similar to the crystallite size in some of our samples. We conclude that the mean crystallite size in our $\mathrm{Sb}_{2} \mathrm{~S}_{3}$ layers is in the general range of values obtained in the literature using both chemical and physical methods.

\section{Morphology of as-deposited and thermally treated $\mathrm{Sb}_{2} \mathrm{~S}_{3}$ layers Influence of deposition temperature on morphology of $\mathrm{Sb}_{2} \mathrm{~S}_{3}$ layers}

The aim of this study was to obtain uniform $\mathrm{Sb}_{2} \mathrm{~S}_{3}$ layers, which continuously coat the $\mathrm{TiO}_{2}$ substrate. According to SEM surface studies, layers deposited from both $\mathrm{Sb} / \mathrm{S} 1: 3$ and $\mathrm{Sb} / \mathrm{S}$ 1:6 solutions at 200 and $210{ }^{\circ} \mathrm{C}$ (3-200-As-dep., 3-210-As-dep., Figure 3G,H, Supporting Information File 1, Figure S2A,B, Figure S3A,B; 6-200-As-dep., Figure 3A,B; 6-210-As-dep., Figure $3 \mathrm{C}, \mathrm{D})$ cover the substrate almost entirely. Grain boundaries and larger clusters of grains have formed in layers deposited from $\mathrm{Sb} / \mathrm{S} \mathrm{1:6}$ solutions for 40 minutes at $210{ }^{\circ} \mathrm{C}$ (6-210-As-dep., Figure 3C,D, Figure S5C,D). Cap-shaped islands $(\varnothing 70 \mathrm{~nm})$ in $\mathrm{Sb}_{2} \mathrm{~S}_{3}$ layers deposited from $\mathrm{Sb} / \mathrm{S}$ 1:6 solution at $T_{\mathrm{D}}=210^{\circ} \mathrm{C}$ for 20 minutes (Figure $\mathrm{S} 4 \mathrm{~A}, \mathrm{~B}$ ), have grown (Ø $100 \mathrm{~nm}$ ) and coalesced further after 40 minutes of deposition at $200-210{ }^{\circ} \mathrm{C}$ (6-200-As-dep., Figure 3A,B, Figure S5A,B; 6-210-As-dep., Figure 3C,D, Figure S5C,D, Figure

\begin{tabular}{|c|c|c|c|c|c|c|}
\hline \multirow{3}{*}{$\begin{array}{l}\mathrm{Sb} / \mathrm{S} \text { in sol. } \\
T_{\mathrm{D}},{ }^{\circ} \mathrm{C}\end{array}$} & \multicolumn{6}{|c|}{$D, \mathrm{~nm}$} \\
\hline & \multicolumn{3}{|c|}{$1: 3$} & \multicolumn{3}{|c|}{$1: 6$} \\
\hline & 200 & 210 & 220 & 200 & 210 & 220 \\
\hline as-dep. & amorph. & amorph. & $33 \pm 10$ & amorph. & $39 \pm 4$ & $47 \pm 1$ \\
\hline vac. $170^{\circ} \mathrm{C}$ & $19 \pm 8$ & $38 \pm 6$ & $100 \pm 23$ & $37 \pm 8$ & $35 \pm 4$ & $49 \pm 3$ \\
\hline vac. $200^{\circ} \mathrm{C}$ & no layer ${ }^{a}$ & $32 \pm 8$ & $67 \pm 12$ & no layer ${ }^{a}$ & $45 \pm 6$ & $52 \pm 3$ \\
\hline
\end{tabular}

${ }^{a} \mathrm{No} \mathrm{Sb}_{2} \mathrm{~S}_{3}$ was detected by XRD or Raman. 


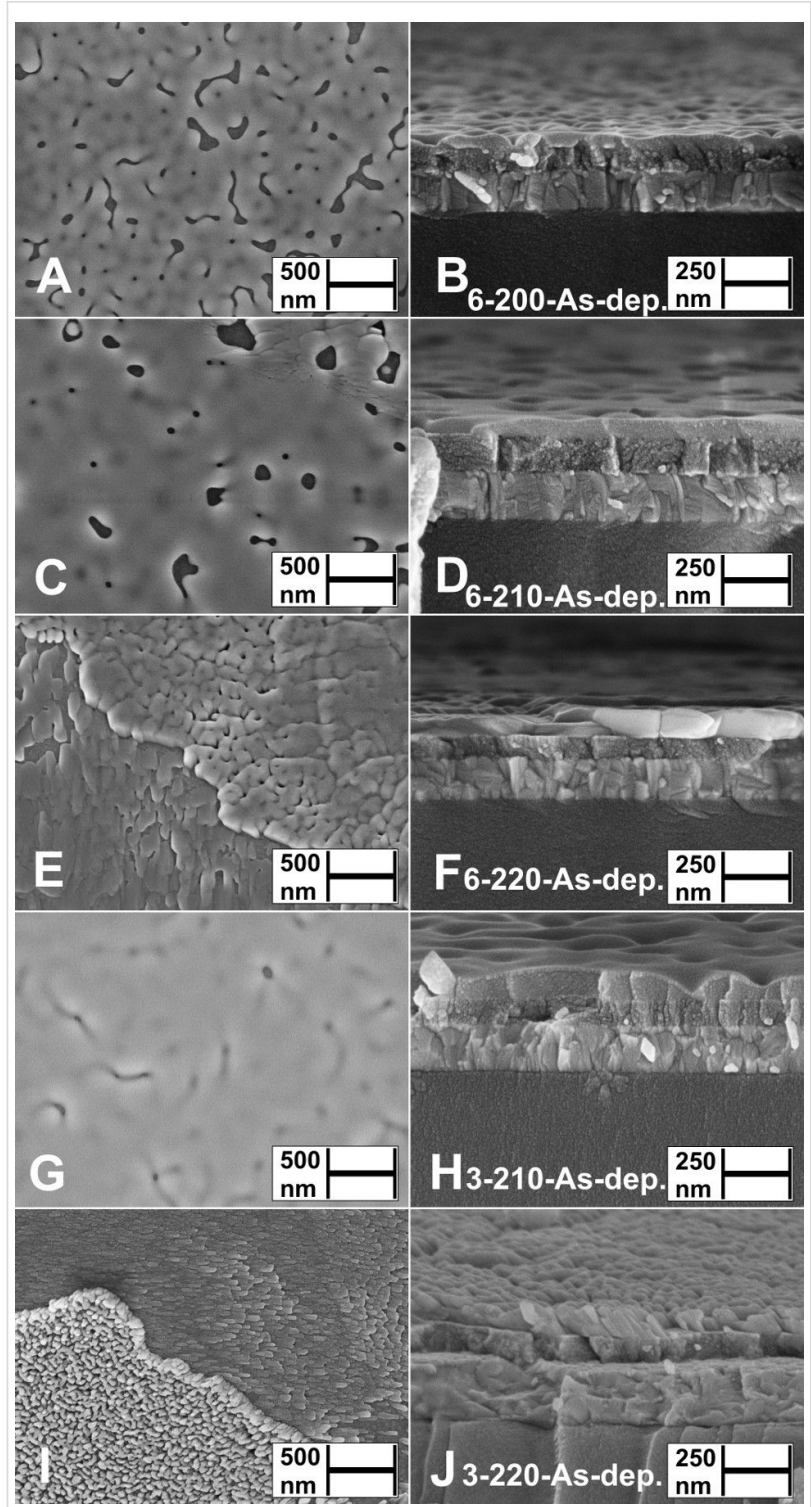

Figure 3: Surface and cross-sectional views by SEM study of as-deposited $\mathrm{Sb}_{2} \mathrm{~S}_{3}$ layers deposited from $\mathrm{Sb} / \mathrm{S} 1: 6$ solution at $T_{\mathrm{D}}=200{ }^{\circ} \mathrm{C}(\mathrm{A}, \mathrm{B}), 210^{\circ} \mathrm{C}(\mathrm{C}, \mathrm{D})$ or $220^{\circ} \mathrm{C}(\mathrm{E}, \mathrm{F})$ and from Sb/S $1: 3$ solution at $T_{\mathrm{D}}=210^{\circ} \mathrm{C}(\mathrm{G}, \mathrm{H})$ or $220^{\circ} \mathrm{C}(\mathrm{I}, \mathrm{J})$ on glass/ITO/TiO ${ }_{2}$ substrate. Sample names in figures: [S/Sb molar ratio in solution]-[deposition temperature]-[as-deposited].

S6A,B), thereby covering the $\mathrm{TiO}_{2}$ substrate to a greater extent. The layers deposited from $\mathrm{Sb} / \mathrm{S} \mathrm{1:6}$ solution at $220{ }^{\circ} \mathrm{C}$ for 40 minutes (6-220-As-dep., Figure 3E,F, Figure S5E,F) consist of various agglomerates, separated by pinholes, and grains flowing randomly along the partially exposed $\mathrm{TiO}_{2}$ substrate (lower left, Figure 3E).

Increasing the deposition temperature from 210 to $220{ }^{\circ} \mathrm{C}$ significantly transforms the surface morphology in $\mathrm{Sb} / \mathrm{S} 1: 3$ layers, as instead of the planar grains (3-210-As-dep., Figure 3G,H) domains of elongated rod-shaped grains (length $\approx 100 \mathrm{~nm}$ ) appear either upright or sideways on the substrate (3-220-Asdep., Figure 3I,J, Figure S3C,D). Rod-shaped $\mathrm{Sb}_{2} \mathrm{~S}_{3}$ grains were able to grow due to the nature of the material as well as due to complex interactions between the substrate and the turbulence of the spray during deposition [29].

Increasing the sulfur precursor concentration in the spray solution from $\mathrm{Sb} / \mathrm{S} \mathrm{1:3}$ to 1:6 (and deposition time from 20 to 40 minutes) yields $\mathrm{Sb}_{2} \mathrm{~S}_{3}$ layers consisting of agglomerated grains (6-220-As-dep., Figure 3E,F). As the deposition time was simultaneously increased from 20 to 40 minutes, it is uncertain whether the morphology of the $\mathrm{Sb}_{2} \mathrm{~S}_{3}$ layers is affected more by the $\mathrm{Sb} / \mathrm{S}$ molar ratio in solution or by the deposition time. $\mathrm{Sb}_{2} \mathrm{~S}_{3}$ tends to yield different morphologies in similar deposition conditions, possibly due to liquid phase reactions between molten-boiling $\mathrm{SbCl}_{3}\left(\mathrm{mp} 73.4{ }^{\circ} \mathrm{C}\right.$, bp $223.5{ }^{\circ} \mathrm{C}$ [30]) and molten thiourea (TU, mp $\left.182{ }^{\circ} \mathrm{C}[14,15]\right)$ catalyzed by the highly active surface of the $\mathrm{TiO}_{2}$ substrate [31].

We have consistently observed twice slower growth of $\mathrm{Sb}_{2} \mathrm{~S}_{3}$ by spraying solutions with $\mathrm{Sb} / \mathrm{S}$ 1:6 (Supporting Information File 1, Figure S4A,B) vs Sb/S 1:3 (Figure 3G,H) molar ratio at 200-220 ${ }^{\circ} \mathrm{C}$. We speculate that doubling the concentration of TU could sterically inhibit the formation of solid $\mathrm{Sb}_{2} \mathrm{~S}_{3}$ nuclei on the surface of the active $\mathrm{TiO}_{2}$ substrate due to more intense bubbling of volatile $\mathrm{TU}$ decomposition products $\left(\mathrm{CS}_{2}, \mathrm{NH}_{3}\right.$, $\mathrm{HCN}, \mathrm{COS}, \mathrm{SO}_{2}, \mathrm{HCl}, \mathrm{HNCS}$ at $200-220^{\circ} \mathrm{C}$ in air based on decomposition studies of pure $\mathrm{TU}$ [14], $\mathrm{Cu}(\mathrm{TU})_{3} \mathrm{Cl}$ [32], $\mathrm{Zn}(\mathrm{TU})_{2} \mathrm{Cl}_{2}$ [33], and $\mathrm{Sn}(\mathrm{TU})_{2} \mathrm{Cl}_{2}$ [34]) in the surrounding liquid phase.

In summary, the most uniform and continuous $\mathrm{Sb}_{2} \mathrm{~S}_{3}$ thin films were deposited from $\mathrm{Sb} / \mathrm{S} 1: 3$ solution at $200-210^{\circ} \mathrm{C}$.

\section{Influence of vacuum treatment temperature on morphology of $\mathrm{Sb}_{2} \mathrm{~S}_{3}$ layers}

The thermal treatment of X-ray amorphous $\mathrm{Sb}_{2} \mathrm{~S}_{3}$ layers (6-200-As-dep., Figure 3A,B; 3-200-As-dep.; 3-210-As-dep., Figure 3G,H, Supporting Information File 1, Figure S2A,B) in vacuum at $170{ }^{\circ} \mathrm{C}$ for 5 minutes yields enhanced substrate coverage at the expense of decreased layer thickness due to coalescence of grains and film formation (6-200-170, Figure 4A,B; 3-200-170, Figure 4G,H; 3-210-170, Figure 4I,J). Complete substrate coverage is observed in the $\mathrm{Sb}_{2} \mathrm{~S}_{3}$ layers deposited at $210{ }^{\circ} \mathrm{C}$ from $\mathrm{Sb} / \mathrm{S} \mathrm{1:3} \mathrm{solution} \mathrm{as} \mathrm{coalescence} \mathrm{is} \mathrm{facilitated}$ during treatment in vacuum at $170{ }^{\circ} \mathrm{C}$ due to the near-continuous coverage of the $\mathrm{TiO}_{2}$ substrate in the as-deposited layers (3-210-170, Figure 4G,H, Figure S2C,D, Figure S7A,B).

Planar grain agglomerates in thermally treated $\mathrm{Sb}_{2} \mathrm{~S}_{3}$ layers (3-210-170, Figure 4G,H, Supporting Information File 1, Figure 


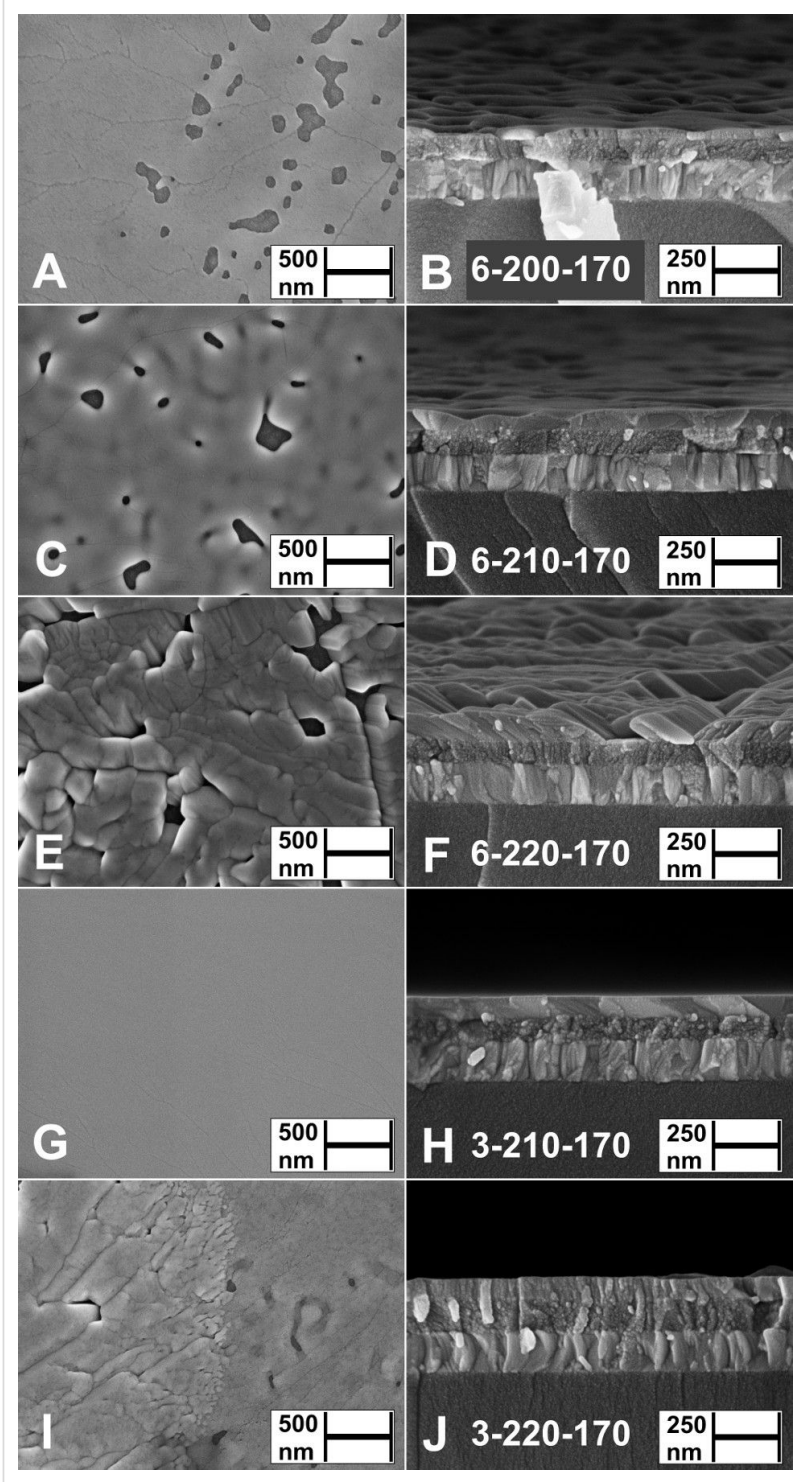

Figure 4: Surface and cross-sectional views by SEM study of thermally treated $\left(170{ }^{\circ} \mathrm{C}, 5\right.$ minutes $) \mathrm{Sb}_{2} \mathrm{~S}_{3}$ layers deposited from $\mathrm{Sb} / \mathrm{S}$ $1: 6$ solution at $T_{\mathrm{D}}=200^{\circ} \mathrm{C}(\mathrm{A}, \mathrm{B}), 210^{\circ} \mathrm{C}(\mathrm{C}, \mathrm{D})$ or $220^{\circ} \mathrm{C}(\mathrm{E}, \mathrm{F})$ and from $\mathrm{Sb} / \mathrm{S} 1: 3$ solution at $T_{\mathrm{D}}=210^{\circ} \mathrm{C}(\mathrm{G}, \mathrm{H})$ or $220^{\circ} \mathrm{C}(\mathrm{I}, \mathrm{J})$ on glass/ $\mathrm{ITO} / \mathrm{TiO}_{2}$ substrates. Sample names in figures: $[\mathrm{S} / \mathrm{Sb}$ molar ratio in solution]-[deposition temperature]-[thermal treatment temperature].
S7A,B; 6-200-170, Figure 4A,B, Figure S9A,B; 6-210-170, Figure 4C,D, Figure S9C,D) range from $100 \mathrm{~nm}$ to over $10 \mu \mathrm{m}$ in size. These agglomerates, consisting of smaller grains separated by ridges, resemble the surface morphology of $300 \mathrm{~nm}$ thick polycrystalline $\mathrm{Sb}_{2} \mathrm{~S}_{3}$ films grown via thermal evaporation and annealed for $10 \mathrm{~min}$ at $300{ }^{\circ} \mathrm{C}$ in $\mathrm{N}_{2}$ [35], and that of metal halide perovskites obtained by Volmer-Weber growth via hot casting [36]. The layers deposited at $220{ }^{\circ} \mathrm{C}$ from both $\mathrm{Sb} / \mathrm{S}$ $1: 3$ and $\mathrm{Sb} / \mathrm{S} 1: 6$ solutions, and thermally treated at $170{ }^{\circ} \mathrm{C}$, consist of numerous grains and pinholes (3-220-170, Figure 4I,J; 6-220-170, Figure 4E,F).

$\mathrm{Sb}_{2} \mathrm{~S}_{3}$ layers deposited at $210{ }^{\circ} \mathrm{C}$ from both $\mathrm{Sb} / \mathrm{S} 1: 3$ and $\mathrm{Sb} / \mathrm{S}$ $1: 6$ solutions, and thermally treated in vacuum at $200{ }^{\circ} \mathrm{C}$ (3-210-200, Figure 5A,B, Supporting Information File 1, Figure S8A,C,E; 6-210-200, Figure 5C,D, Figure S8B,D,F), are porous, inhomogeneous and $\approx 20 \mathrm{~nm}$ thinner (Table 3 ) vs the uniform in thickness layers after treatment at $170{ }^{\circ} \mathrm{C}(3-210-$ 170, Figure 4I,J; 6-210-170, Figure 4C,D).

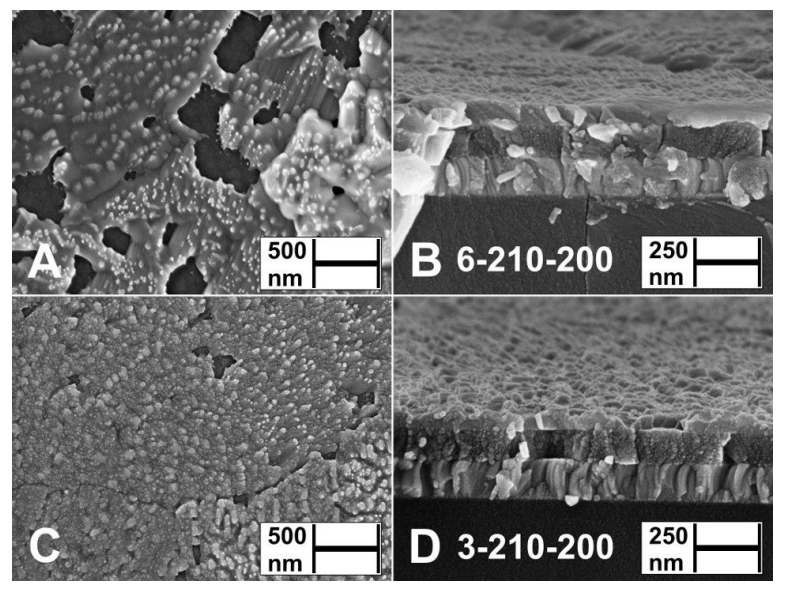

Figure 5: Surface and cross-sectional views by SEM study of vacuum treated $\left(200{ }^{\circ} \mathrm{C}, 5\right.$ minutes) $\mathrm{Sb}_{2} \mathrm{~S}_{3}$ layers deposited from $\mathrm{Sb} / \mathrm{S} 1: 6$ solution (A, B) and from $\mathrm{Sb} / \mathrm{S} 1: 3$ solution $(\mathrm{C}, \mathrm{D})$ at $T_{\mathrm{D}}=210^{\circ} \mathrm{C}$ on glass//TO/TiO 2 substrates. Sample names in figures: [S/Sb molar ratio in solution]-[deposition temperature]-[thermal treatment temperature].

Table 3: Thicknesses of $\mathrm{Sb}_{2} \mathrm{~S}_{3}$ layers estimated from SEM images.

$\mathrm{Sb}_{2} \mathrm{~S}_{3}$ layer thickness, $\mathrm{nm}$

$\mathrm{Sb} / \mathrm{S} 1: 3$ in sol., $20 \mathrm{~min}$ dep.

$\mathrm{Sb} / \mathrm{S} 1: 6$ in sol., $40 \mathrm{~min}$ dep.

\begin{tabular}{|c|c|c|c|c|c|c|}
\hline$T_{\mathrm{D}},{ }^{\circ} \mathrm{C}$ & 200 & 210 & 220 & 200 & 210 & 220 \\
\hline as-dep. & $70-90$ & $80-100$ & $60 / 150^{a}$ & $50-70$ & $60 / 400^{a}$ & $40 / 400^{a}$ \\
\hline vac., $170^{\circ} \mathrm{C}$ & $70-90$ & $70-90$ & $80 / 150^{a}$ & $30-40$ & $60 / 400^{a}$ & $40 / 400^{a}$ \\
\hline vac., $200^{\circ} \mathrm{C}$ & no layer ${ }^{b}$ & $60-70$ & $\mathrm{~N} / \mathrm{A}$ & no layer ${ }^{b}$ & $60-70$ & $\mathrm{~N} / \mathrm{A}$ \\
\hline
\end{tabular}

aThickness of formations shown in the Supporting Information File 1 in Figures S5, S7, S8 and S9. b No Sb ${ }_{2} \mathrm{~S}_{3}$ was detected by XRD or Raman. 
The decreasing layer thickness indicates that approximately a quarter of $\mathrm{Sb}_{2} \mathrm{~S}_{3}$ by volume has either evaporated or sublimated, i.e., volatilized. Incongruent evaporation, i.e., depletion of sulfur in $\mathrm{Sb}_{2} \mathrm{~S}_{3}$ during evaporation, may cause the change in $\mathrm{Sb}_{2} \mathrm{~S}_{3}$ layer morphology, as volatilization of the planar regions around the nucleating islands has been reported during thermal treatment of both $\mathrm{Sb}_{2} \mathrm{Se}_{3}$ layers grown via thermal evaporation [37] and oxide containing $\mathrm{Sb}_{2} \mathrm{~S}_{3}$ layers grown via CBD [16].

The calculated vapor pressure of $\mathrm{Sb}_{2} \mathrm{~S}_{3}$ is $\approx 2 \times 10^{-10}$ Torr at $170{ }^{\circ} \mathrm{C}, 7 \times 10^{-9}$ Torr at $200{ }^{\circ} \mathrm{C}$ and $9 \times 10^{-7}$ Torr at $250{ }^{\circ} \mathrm{C}$ [38], whereas the dynamic system pressure is $\approx 4 \times 10^{-6}$ Torr. The calculated partial pressure of $\mathrm{Sb}_{2} \mathrm{~S}_{3}$ is $\approx 0.0050 \%$ at $170{ }^{\circ} \mathrm{C}$, $0.18 \%$ at $200{ }^{\circ} \mathrm{C}$ and $23 \%$ at $250{ }^{\circ} \mathrm{C}$ (Comment S1 in Supporting Information File 1). The loss of a quarter of the $\mathrm{Sb}_{2} \mathrm{~S}_{3}$ layer thickness in samples that were vacuum annealed at 200 vs $170{ }^{\circ} \mathrm{C}$ (Table 3) correlates with the exponential increase in $\mathrm{Sb}_{2} \mathrm{~S}_{3}$ vapor pressure in the $170-250{ }^{\circ} \mathrm{C}$ range.

In conclusion, the most uniform and continuous $\mathrm{Sb}_{2} \mathrm{~S}_{3}$ thin films were produced by vacuum treatment at $170{ }^{\circ} \mathrm{C}$ for $5 \mathrm{~min}$ of $\mathrm{Sb}_{2} \mathrm{~S}_{3}$ layers deposited from $\mathrm{Sb} / \mathrm{S}$ 1:3 solution at $200-210{ }^{\circ} \mathrm{C}$.

\section{Elemental composition of as-deposited and thermally treated $\mathrm{Sb}_{2} \mathrm{~S}_{3}$ layers}

The elemental composition of $\mathrm{Sb}_{2} \mathrm{~S}_{3}$ in as-deposited and thermally treated glass/ITO/TiO $/ \mathrm{Sb}_{2} \mathrm{~S}_{3}$ samples was determined using energy dispersive X-ray spectroscopy (EDX). The EDX results of studied $\mathrm{Sb}_{2} \mathrm{~S}_{3}$ layers in terms of $\mathrm{S}$ to $\mathrm{Sb}$ atomic ratio $(\mathrm{S} / \mathrm{Sb})$ are presented in Table $4 . \mathrm{S} / \mathrm{Sb}$ in both as-deposited and vacuum annealed polycrystalline $\mathrm{Sb}_{2} \mathrm{~S}_{3}$ layers deposited at $T_{\mathrm{D}}=220{ }^{\circ} \mathrm{C}$ is close to the stoichiometric value of $1.5 \mathrm{of} \mathrm{Sb}_{2} \mathrm{~S}_{3}$, whereas the $\mathrm{S} / \mathrm{Sb}$ ratio of as-deposited and thermally treated $\mathrm{Sb}_{2} \mathrm{~S}_{3}$ layers $\left(\mathrm{Sb} / \mathrm{S} 1: 3\right.$ in solution, $T_{\mathrm{D}} 200-210{ }^{\circ} \mathrm{C}, 3-200$-Asdep., 3-210-As-dep., 3-200-170, 3-210-170) is $\approx 1.3$. S/Sb is $\approx 1.5-1.6$ in layers deposited from $\mathrm{Sb} / \mathrm{S} 1: 6$ solution at $200-220{ }^{\circ} \mathrm{C}$.

Table 4: $\mathrm{S} / \mathrm{Sb}$ atomic ratio of as-deposited and thermally treated $\mathrm{Sb}_{2} \mathrm{~S}_{3}$ layers calculated from EDX data.

\begin{tabular}{|c|c|c|c|c|c|c|}
\hline \multirow{3}{*}{$\begin{array}{l}\mathrm{Sb} / \mathrm{S} \text { in sol. } \\
T_{\mathrm{D}},{ }^{\circ} \mathrm{C}\end{array}$} & \multicolumn{6}{|c|}{$\mathrm{S} / \mathrm{Sb}$ in layer } \\
\hline & \multicolumn{3}{|c|}{$1: 3$} & \multicolumn{3}{|c|}{$1: 6$} \\
\hline & 200 & 210 & 220 & 200 & 210 & 220 \\
\hline as-dep. & 1.3 & 1.3 & 1.5 & 1.6 & 1.5 & 1.5 \\
\hline vac., $170^{\circ} \mathrm{C}$ & 1.3 & 1.3 & 1.5 & 1.6 & 1.6 & 1.5 \\
\hline vac., $200^{\circ} \mathrm{C}$ & $\mathrm{N} / \mathrm{A}$ & 1.4 & N/A & N/A & 1.5 & N/A \\
\hline
\end{tabular}

We note that interpretation of EDX spectra of very thin layers is difficult. Most of our $\mathrm{Sb}_{2} \mathrm{~S}_{3}$ layers are thinner than $100 \mathrm{~nm}$, which could explain the divergence in the elemental composition of our $\mathrm{Sb}_{2} \mathrm{~S}_{3}$ layers. Therefore, future studies by more surface sensitive methods are required. Overall, $\mathrm{S} / \mathrm{Sb}$ in most studied samples approximates the stoichiometric value of 1.5 of $\mathrm{Sb}_{2} \mathrm{~S}_{3}$.

Oxygen could not be quantified by EDX due to the thin layers and high concentration of $\mathrm{O}$ in the glass $/ \mathrm{ITO} / \mathrm{TiO}_{2}$ substrate. In addition, $\mathrm{C}$ and $\mathrm{Cl}$ levels were below the detection limit of the used EDX setup in all studied $\mathrm{Sb}_{2} \mathrm{~S}_{3}$ layers, meaning most $\mathrm{C}$ and $\mathrm{Cl}$ species exit the growing $\mathrm{Sb}_{2} \mathrm{~S}_{3}$ layer during deposition in open environment (Supporting Information File 1, Figure S11). We believe that this reinforces our claim that formation of $\mathrm{Sb}_{2} \mathrm{~S}_{3}$ proceeds through a molten phase reaction between $\mathrm{SbCl}_{3}$ and TU, where the denser $\left(4562 \mathrm{~kg} / \mathrm{m}^{3}\right.$ [39]) $\mathrm{Sb}_{2} \mathrm{~S}_{3}$ precipitates and nucleates, while the remainder of the volatile compounds $\left(\mathrm{SbCl}_{3}\right.$, and various decomposition products of $\left.\mathrm{TU}\right)$ exit the system $[14,15,38,40]$.

\section{Growth mechanism of $\mathrm{Sb}_{2} \mathrm{~S}_{3}$ layers by spray pyrolysis}

The three most common growth mechanisms of solids can be described by the following equations [41]:

$$
\begin{aligned}
& \sigma_{\mathrm{SG}}>\sigma_{\mathrm{LG}}+\sigma_{\mathrm{SL}} \\
& \sigma_{\mathrm{SG}}<\sigma_{\mathrm{LG}}+\sigma_{\mathrm{SL}} \\
& \sigma_{\mathrm{SG}} \approx \sigma_{\mathrm{LG}}+\sigma_{\mathrm{SL}}
\end{aligned}
$$

Where $\sigma_{\mathrm{SG}}$ is the surface free energy of the substrate-gas interface $\left(\mathrm{TiO}_{2}-\right.$ air $), \sigma_{\mathrm{LG}}$ is the surface free energy of the layer-gas interface $\left(\mathrm{Sb}_{2} \mathrm{~S}_{3}\right.$-air) and $\sigma_{\mathrm{SL}}$ is the surface free energy of the substrate-layer interface $\left(\mathrm{TiO}_{2}-\mathrm{Sb}_{2} \mathrm{~S}_{3}\right)$. The surface free energy $(\sigma)$ is the driving force of fluids and solids to seek a condition of minimum energy by contracting interfacial surface area [41]. Separate 3D islands grow if Equation 1 is valid, a.k.a. Volmer-Weber growth; 2D layer-by-layer growth occurs if Equation 2 is valid, a.k.a. Frank-Van der Merwe growth; combined 2D layer-by layer and 3D island growth occurs if Equation 3 is valid, a.k.a. Stranski-Krastanov growth [36,4143].

Furthermore, SEM surface studies show cap-shaped islands indicative of Volmer-Weber growth in $\mathrm{Sb}_{2} \mathrm{~S}_{3}$ layers deposited on $\mathrm{Si} / \mathrm{SiO}_{2}$ alternative substrates by ultrasonic spraying (Supporting Information File 1, Figure S10A,B). Metastibnite- $\mathrm{Sb}_{2} \mathrm{~S}_{3}$ forms when formation of stibnite- $\mathrm{Sb}_{2} \mathrm{~S}_{3}$ is halted by insufficient reaction time and energy [44-46]. Volmer-Weber island growth of amorphous $\mathrm{Sb}_{2} \mathrm{~S}_{3}$ (and in some cases leaf-like grains of polycrystalline $\mathrm{Sb}_{2} \mathrm{~S}_{3}$ ) have been observed in $\mathrm{Sb}_{2} \mathrm{~S}_{3}$ layers 
grown by chemical bath deposition on glass $[47,48], \mathrm{In}_{2} \mathrm{O}_{3} / \mathrm{Sn}$ (ITO) [49], planar $\mathrm{TiO}_{2}$ [16] and $\mathrm{TiO}_{2}$ nanotube arrays [50], by sequential deposition [51] and spin coating [8,52] on planar $\mathrm{TiO}_{2}$, by photochemical deposition on mesoporous $\mathrm{TiO}_{2}$ [53], by thermal evaporation on planar CdS [27] and planar $\mathrm{TiO}_{2}$ [54]. Supported by these numerous observations, we consider the Volmer-Weber growth characteristic of $\mathrm{Sb}_{2} \mathrm{~S}_{3}$, given that the substrate and deposition conditions are met. Indeed, metastibnite, the naturally occurring mineral form of amorphous $\mathrm{Sb}_{2} \mathrm{~S}_{3}$, has the botryoidal characteristic, preferentially forming globular clusters [55]. We have also observed 3D growth of extremely thin $\mathrm{TiO}_{2}$ layers by spray pyrolysis [56]. Therefore, $3 \mathrm{D}$ island growth may partially be imposed by the use of the spray pyrolysis method as well.

Based on the above observations, the morphology and crystallinity of as-deposited layers seems to determine the nature of $\mathrm{Sb}_{2} \mathrm{~S}_{3}$ layer morphology as formed during vacuum thermal treatment. Our proposed growth mechanism of $\mathrm{Sb}_{2} \mathrm{~S}_{3}$ by ultrasonic spraying in air is illustrated in Figure 6.

\section{Optical properties of as-deposited and thermally treated $\mathrm{Sb}_{2} \mathrm{~S}_{3}$ layers}

The absorption coefficient $(\alpha)$ and band gap $\left(E_{\mathrm{g}}\right)$ values of $\mathrm{Sb}_{2} \mathrm{~S}_{3}$ in both as-deposited and thermally treated glass/ITO/ $\mathrm{TiO}_{2} / \mathrm{Sb}_{2} \mathrm{~S}_{3}$ samples were determined using an approximated $\mathrm{Sb}_{2} \mathrm{~S}_{3}$ layer thickness of $100 \mathrm{~nm}$ derived from SEM images (Table 3). The absorption coefficient $\alpha$ was determined as

$$
\alpha=d^{-1} \ln \left[(1-R) T^{-1}\right]
$$

where $d$ is the layer thickness, $R$ is the total reflectance, included to compensate for thin film interference, and $T$ is the total transmittance.

The band gap of $\mathrm{Sb}_{2} \mathrm{~S}_{3}$ layers was determined by plotting $(\alpha h v)^{1 / \mathrm{r}}$ vs $h v$, where $h$ is the Planck constant, $v$ is the frequency and $r=1 / 2$ is the exponent corresponding to the assumed direct optical transition [57]. Extrapolating the linear region of this curve to the $h v$-axis yields the optical band gap. Thin film interference could not be completely removed by accounting for reflectance in $\alpha$ calculations. Thus, the absolute values of $\alpha$ may deviate from the expected values with the uncertainty introduced by using a constant layer thickness in calculations.

The $\alpha$ vs wavelength plots of samples, which contain as-deposited or vacuum-treated $\mathrm{Sb}_{2} \mathrm{~S}_{3}$ layers deposited from $\mathrm{Sb} / \mathrm{S}$ 1:3 solution, are shown in Figure 7A. Likewise, $\alpha$ vs wavelength plots of $\mathrm{Sb} / \mathrm{S}$ 1:6 samples are shown in Figure 7B. The $\alpha$ in samples containing amorphous $\mathrm{Sb}_{2} \mathrm{~S}_{3}$ increases steadily from $10^{3}-10^{4} \mathrm{~cm}^{-1}$ at $600-800 \mathrm{~nm}$ to $10^{5} \mathrm{~cm}^{-1}$ at around $400 \mathrm{~nm}$. The $\alpha$ increases significantly faster in samples containing as-grown crystalline $\mathrm{Sb}_{2} \mathrm{~S}_{3}$ or vacuum crystallized $\mathrm{Sb}_{2} \mathrm{~S}_{3}$. The value of $\alpha$ surges by an order of magnitude from around $10^{4} \mathrm{~cm}^{-1}$ to $10^{5} \mathrm{~cm}^{-1}$ as the wavelength decreases from $750 \mathrm{~nm}$ to $650 \mathrm{~nm}$ due to the onset of absorption in crystalline $\mathrm{Sb}_{2} \mathrm{~S}_{3}$. At shorter wavelengths beyond the absorption edge, $\alpha$ increases at a slower rate, from around $10^{5} \mathrm{~cm}^{-1}$ at $650 \mathrm{~nm}$ to more than $5 \times 10^{5} \mathrm{~cm}^{-1}$ at $300 \mathrm{~nm}$. The optical absorption results are in agreement with $\mathrm{XRD}$, which shows that these samples (3-220-As-dep., 3-210-170, 6-210-As-dep. and 6-200170) contain orthorhombic $\mathrm{Sb}_{2} \mathrm{~S}_{3}$ (Figure $2 \mathrm{~A}, \mathrm{~B}$ ). Comparing the $\alpha$ spectra of samples containing amorphous and crystalline

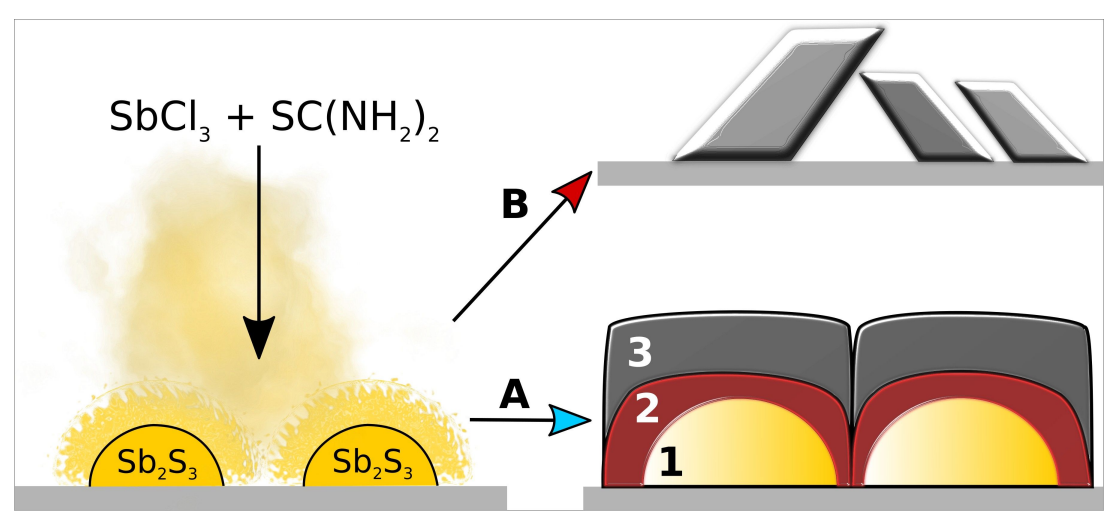

Figure 6: Proposed growth mechanism paths of $\mathrm{Sb}_{2} \mathrm{~S}_{3}$ by Volmer-Weber growth during ultrasonic spraying of methanolic solution of $\mathrm{SbCl}_{3}-\mathrm{SC}\left(\mathrm{NH}_{2}\right)_{2}$ in excess of sulfur precursor in aerosol. Amorphous $\mathrm{Sb}_{2} \mathrm{~S}_{3}$ nucleates after precipitation from a molten $\mathrm{SbCl}{ }_{3}-\mathrm{SC}\left(\mathrm{NH}_{2}\right)_{2}$ mixture: $\mathrm{A}-$ Amorphous $\mathrm{Sb}_{2} \mathrm{~S}_{3}$ islands nucleate on the rigid $\mathrm{TiO}_{2}$ substrate and grow by $3 \mathrm{D}$ Volmer-Weber growth, surrounded by a protective bubbling liquid film of volatile $\mathrm{SbCl}_{3}$ and $\mathrm{TU}$ decomposition products (1), eventually interconnecting by coalescence of sufficiently large islands to minimize $\mathrm{Sb}_{2} \mathrm{~S}_{3}-$ air

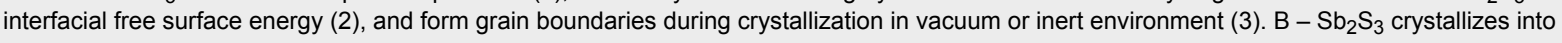
separate grains if either the deposition temperature, the deposition time or the excess of $\mathrm{TU}$ in $\mathrm{Sb} / \mathrm{S}$ precursor molar ratio exceed a critical value before or during process A, i.e., the energetic threshold for crystallization is surpassed. 

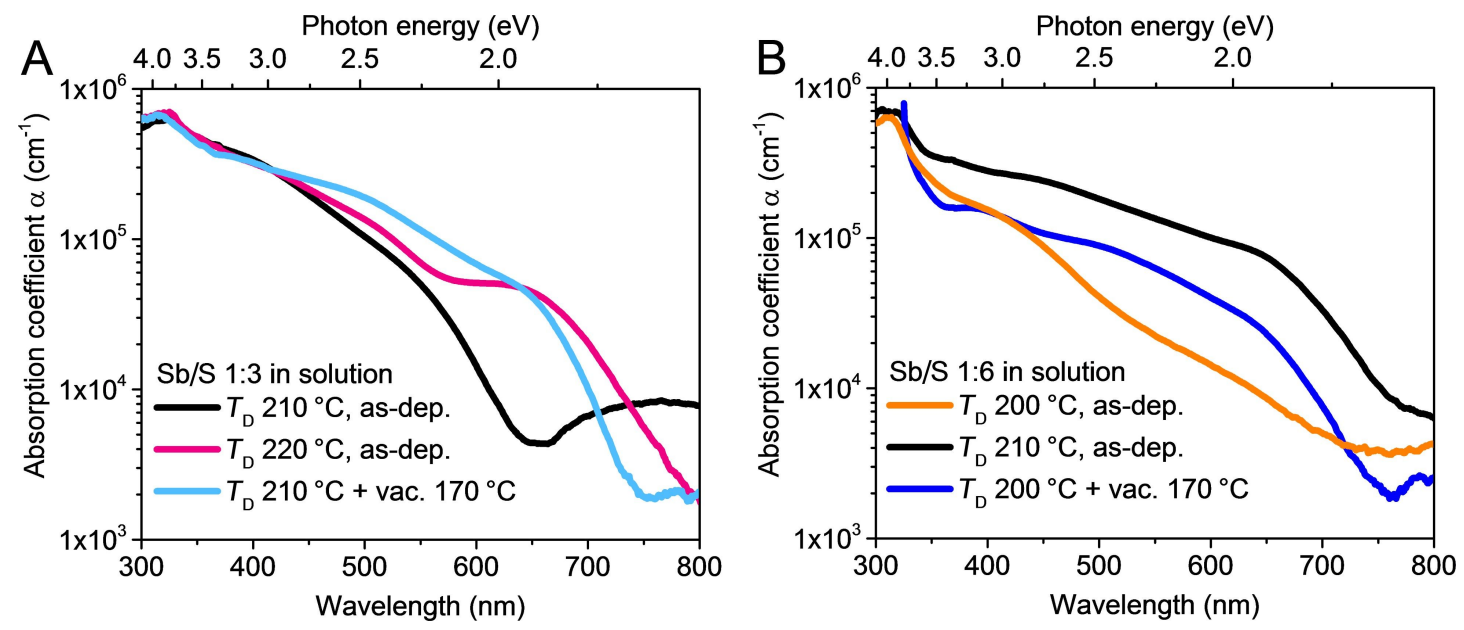

Figure 7: Absorption coefficient $(\alpha)$ vs wavelength of glass/ITO/TiO ${ }_{2} / \mathrm{Sb}_{2} \mathrm{~S}_{3}$ samples incorporating as-deposited and vacuum treated $\left(170{ }^{\circ} \mathrm{C}\right.$ 5 minutes) $\mathrm{Sb}_{2} \mathrm{~S}_{3}$ layers. The $\alpha$ of glass/ITO/TiO ${ }_{2}$ substrates is not shown as it is negligible at the presented wavelengths. $\mathrm{Sb}_{2} \mathrm{~S}_{3}$ layers were deposited from $\mathrm{Sb} / \mathrm{S} 1: 3$ solution at $210{ }^{\circ} \mathrm{C}, 220^{\circ} \mathrm{C}(\mathrm{A})$ and from $\mathrm{Sb} / \mathrm{S} 1: 6$ solution at $200{ }^{\circ} \mathrm{C}$ and $210{ }^{\circ} \mathrm{C}(\mathrm{B})$.

$\mathrm{Sb}_{2} \mathrm{~S}_{3}$ further confirms that the $\mathrm{Sb}_{2} \mathrm{~S}_{3}$ layers deposited from $\mathrm{Sb} / \mathrm{S} \mathrm{1:3} \mathrm{solution} \mathrm{at} 200-210{ }^{\circ} \mathrm{C}$, and from $\mathrm{Sb} / \mathrm{S}$ 1:6 solution at $200{ }^{\circ} \mathrm{C}$, are indeed amorphous. Namely, $\alpha$ is an order of magnitude smaller at around $600 \mathrm{~nm}$ in samples containing amorphous $\mathrm{Sb}_{2} \mathrm{~S}_{3}$ layers (3-210-As-dep. and 6-200-As-dep.).

The experimentally determined $E_{\mathrm{g}}$ are $\approx 2.7$ and $1.8 \mathrm{eV}$ for amorphous and polycrystalline $\mathrm{Sb}_{2} \mathrm{~S}_{3}$, respectively (Table 5, Tauc plots in Supporting Information File 1, Figure S12). In comparison, $E_{\mathrm{g}}$ of amorphous $\mathrm{CBD}-\mathrm{Sb}_{2} \mathrm{~S}_{3}$ on glass substrates is $\approx 2.5 \mathrm{eV}$ [58] and $E_{\mathrm{g}}$ of polycrystalline $\mathrm{Sb}_{2} \mathrm{~S}_{3}$ prepared by physical and chemical methods is commonly reported as $1.6-1.8 \mathrm{eV}$ [1,22,58-60]. As such, we find the $E_{\mathrm{g}}$ of our polycrystalline $\mathrm{Sb}_{2} \mathrm{~S}_{3}$ layers lies satisfactorily in the range of published values.

Table 5: Band gap $\left(E_{\mathrm{g}}\right)$ of as-deposited and thermally treated $\mathrm{Sb}_{2} \mathrm{~S}_{3}$ layers, as estimated assuming direct optical transition and Tauc plots ${ }^{a}$ of optical transmittance spectra of glass/ITO/TiO $/ \mathrm{Sb}_{2} \mathrm{~S}_{3}$ samples.

\begin{tabular}{|c|c|c|c|c|c|c|}
\hline \multirow{3}{*}{$\begin{array}{l}\text { Sb/S in sol. } \\
T_{\mathrm{D}},{ }^{\circ} \mathrm{C}\end{array}$} & \multicolumn{6}{|c|}{$E_{\mathrm{g}}, \mathrm{eV}$} \\
\hline & \multicolumn{3}{|c|}{$1: 3$} & \multicolumn{3}{|c|}{$1: 6$} \\
\hline & 200 & 210 & 220 & 200 & 210 & 220 \\
\hline as-dep. & 2.6 & 2.7 & 1.8 & 2.7 & 1.8 & 1.8 \\
\hline vac. $170^{\circ} \mathrm{C}$ & 1.8 & 1.8 & 1.8 & 1.8 & 1.8 & 1.8 \\
\hline vac. $200^{\circ} \mathrm{C}$ & no layer ${ }^{b}$ & 1.8 & 1.8 & no layer ${ }^{b}$ & 1.8 & 1.8 \\
\hline
\end{tabular}

aSupporting Information File 1, Figure S12A,B. ${ }^{b} \mathrm{No} \mathrm{Sb}_{2} \mathrm{~S}_{3}$ was detected by XRD or Raman.

\section{Conclusion}

The structure, the morphology, and the optical properties of $\mathrm{Sb}_{2} \mathrm{~S}_{3}$ layers could be controlled by varying the spray deposi- tion temperature and the molar ratio of precursors in spray solution. Nonuniform, discontinuous layers of polycrystalline $\mathrm{Sb}_{2} \mathrm{~S}_{3}$ $\left(E_{\mathrm{g}} 1.8 \mathrm{eV}\right.$ ) were deposited by ultrasonic spray pyrolysis of $\mathrm{SbCl}_{3} / \mathrm{SC}\left(\mathrm{NH}_{2}\right)_{2} 1: 3$ solution at $T_{\mathrm{D}} \geq 220{ }^{\circ} \mathrm{C}$ or $1: 6$ solution at $T_{\mathrm{D}} \geq 210^{\circ} \mathrm{C}$ on glass $/ \mathrm{ITO} / \mathrm{TiO}_{2}$ substrates in air. Increasing the concentration of the sulfur precursor in spray solution from $\mathrm{Sb} / \mathrm{S} 1: 3$ to 1:6 reduced the crystallization temperature of $\mathrm{Sb}_{2} \mathrm{~S}_{3}$ layers by $\approx 10{ }^{\circ} \mathrm{C}$. Uniform layers of amorphous $\mathrm{Sb}_{2} \mathrm{~S}_{3}$ ( $E_{\mathrm{g}} \approx 2.7 \mathrm{eV}, \mathrm{S} / \mathrm{Sb} 1: 3$ ) were deposited on glass $/ \mathrm{ITO} / \mathrm{TiO}{ }_{2}$ substrates in air by ultrasonic spray pyrolysis of $\mathrm{Sb} / \mathrm{S} 1: 3$ solution at $T_{\mathrm{D}}=200-210^{\circ} \mathrm{C}$. High quality, uniform, pinhole-free coatings of polycrystalline orthorhombic $\mathrm{Sb}_{2} \mathrm{~S}_{3}\left(E_{\mathrm{g}} 1.8 \mathrm{eV}, \mathrm{S} / \mathrm{Sb}\right.$ 1.3) with lateral grain size as large as $10 \mu \mathrm{m}$ were produced by crystallization of amorphous $\mathrm{Sb}_{2} \mathrm{~S}_{3}$ layers in vacuum at $170{ }^{\circ} \mathrm{C}$ for 5 minutes. Such $\mathrm{Sb}_{2} \mathrm{~S}_{3}$ optical coatings are very attractive for future application as low-cost absorber layers in solar cells.

\section{Experimental Materials}

Commercial $1.1 \mathrm{~mm}$ thick soda-lime glass coated with $150 \mathrm{~nm}$ $25 \Omega \cdot \mathrm{sq}^{-1}$ tin doped indium oxide (ITO) from ZSW was used as a substrate. The substrates were rinsed with deionized water, methanol (99.9 vol \%), deionized water, dipped in aqueous room temperature $\mathrm{H}_{2} \mathrm{SO}_{4}$ (1 vol \%), rinsed again with deionized water, and dried at $105{ }^{\circ} \mathrm{C}$ in air.

$\mathrm{TiO}_{2}$ was prepared by methods used in our previous papers $[7,12]$. The $\mathrm{TiO}_{2}$ film thickness was $\approx 80 \mathrm{~nm}$ based on SEM images. The $\mathrm{Sb}_{2} \mathrm{~S}_{3}$ layers were deposited from $30 \mathrm{mM} \mathrm{SbCl}_{3}$ (99 wt \%) and $\mathrm{SC}\left(\mathrm{NH}_{2}\right)_{2}$ (99 wt \%) methanolic (99.9 vol \%) 
solutions at molar ratios of $\mathrm{Sb} / \mathrm{S} \mathrm{1:3}$ and $\mathrm{Sb} / \mathrm{S} \mathrm{1:6.} \mathrm{All} \mathrm{chemi-}$ cals were purchased from Sigma-Aldrich and used without any additional processing. The precursor solutions were prepared inside a glovebox with controlled humidity $(<14 \mathrm{ppm})$.

The solutions were ultrasonically nebulized and guided by compressed air at a flow rate of $5 \mathrm{~L} \cdot \mathrm{min}^{-1}$ onto glass $/ \mathrm{ITO} / \mathrm{TiO}_{2}$ substrates at deposition temperatures of 200,210 , and $220{ }^{\circ} \mathrm{C}$ for $20 \mathrm{~min}(\mathrm{Sb} / \mathrm{S} \mathrm{1:3)}$ or $40 \mathrm{~min}(\mathrm{Sb} / \mathrm{S} \mathrm{1:6)}$. After deposition, some of the samples were thermally treated in dynamic vacuum $\left(<4 \times 10^{-6}\right.$ Torr $)$ at 170,200 or $250^{\circ} \mathrm{C}$ for $5 \mathrm{~min}$. The average heating and cooling rate was $\approx 8^{\circ} \mathrm{C} \cdot \mathrm{min}^{-1}$.

\section{Characterization}

The elemental composition of the films was determined by energy dispersive X-ray spectroscopy (EDX) using a Bruker spectrometer with ESPRIT 1.8 system at the Zeiss HR FESEM Ultra 55 scanning electron microscope (SEM) operating at an accelerating voltage of $7 \mathrm{kV}$. The surface and cross-sectional morphologies of the layers were recorded by the same SEM system at an electron beam accelerating voltage of $4 \mathrm{kV}$.

Unpolarized micro-Raman measurements were conducted at room temperature using a Horiba Jobin Yvon Labram HR 800 spectrometer in backscattering geometry. The laser intensity was attenuated to ca. $143 \mu \mathrm{W} \cdot \mu \mathrm{m}^{-2}$ over a focal area of $\varnothing 5 \mu \mathrm{m}$ to prevent oxidation of the $\mathrm{Sb}_{2} \mathrm{~S}_{3}$ layers, a common oversight according to Kharbish et al. [21]. Deconvoluted band centers in Raman shift, band intensities and full widths at half maximum (FWHM) were fitted using a Lorentzian function [61].

X-ray diffraction (XRD) patterns were recorded on a Rigaku Ultima IV powder diffractometer in $\theta-2 \theta$ mode $\left(\mathrm{Cu} \mathrm{K} \alpha_{1}\right.$ $\lambda=1.5406 \AA, 40 \mathrm{kV}, 40 \mathrm{~mA}$, step $0.02^{\circ}, 5^{\circ} / \mathrm{min}$, silicon strip detector $\mathrm{D} /$ teX Ultra). The crystal structure and phase composition were analyzed using Rigaku PDXL 2 software.

Optical total transmittance and total reflectance spectra of glass/ ITO/TiO 2 reference and glass/ITO/ $\mathrm{TiO}_{2} / \mathrm{Sb}_{2} \mathrm{~S}_{3}$ samples were measured in the $250-1600 \mathrm{~nm}$ range vs air as a reference using a Jasco V-670 UV-VIS-NIR spectrophotometer equipped with a $40 \mathrm{~mm}$ integrating sphere and Spectra Manager II software.

\section{Supporting Information}

\section{Supporting Information File 1}

Additional XRD, EDX data, SEM images, Lorentzian fitting of $\mathrm{Sb}_{2} \mathrm{~S}_{3}$ Raman vibrational bands, and Tauc plots. [https://www.beilstein-journals.org/bjnano/content/ supplementary/2190-4286-10-18-S1.pdf]

\section{Acknowledgements}

We acknowledge Dr. Valdek Mikli from the Laboratory of Optoelectronic Materials Physics at Tallinn University of Technology for recording SEM images and EDX measurements, Estonian Research Council project IUT19-4 "Thin films and nanomaterials by wet-chemical methods for next-generation photovoltaics" and European Regional Development Fund project TK141 "Advanced materials and high-technology devices for sustainable energetics, sensorics and nanoelectronics" for funding.

\section{ORCID ${ }^{\circledR} \mathrm{iDs}$}

Jako S. Eensalu - https://orcid.org/0000-0002-4312-0227 Atanas Katerski - https://orcid.org/0000-0003-1980-3391 Erki Kärber - https://orcid.org/0000-0001-6157-3070 Ilona Oja Acik - https://orcid.org/0000-0002-1870-3543 Arvo Mere - https://orcid.org/0000-0001-9070-3970 Malle Krunks - https://orcid.org/0000-0003-4658-4403

\section{References}

1. Versavel, M. Y.; Haber, J. A. Thin Solid Films 2007, 515, 7171-7176. doi:10.1016/j.tsf.2007.03.043

2. Messina, S.; Nair, M. T. S.; Nair, P. K. Thin Solid Films 2007, 515, 5777-5782. doi:10.1016/j.tsf.2006.12.155

3. Itzhaik, Y.; Niitsoo, O.; Page, M.; Hodes, G. J. Phys. Chem. C 2009, 113, 4254-4256. doi:10.1021/jp900302b

4. Choi, Y. C.; Lee, D. U.; Noh, J. H.; Kim, E. K.; Seok, S. I. Adv. Funct. Mater. 2014, 24, 3587-3592. doi:10.1002/adfm.201304238

5. Choi, Y. C.; Seok, S. I. Adv. Funct. Mater. 2015, 25, 2892-2898. doi:10.1002/adfm.201500296

6. Wedemeyer, H.; Michels, J.; Chmielowski, R.; Bourdais, S.; Muto, T.; Sugiura, M.; Dennler, G.; Bachmann, J. Energy Environ. Sci. 2013, 6, 67-71. doi:10.1039/c2ee23205g

7. Parize, R.; Katerski, A.; Gromyko, I.; Rapenne, L.; Roussel, H.; Kärber, E.; Appert, E.; Krunks, M.; Consonni, V. J. Phys. Chem. C 2017, 121, 9672-9680. doi:10.1021/acs.jpcc.7b00178

8. Sung, S.-J.; Gil, E. K.; Lee, S.-J.; Choi, Y. C.; Yang, K.-J.; Kang, J.-K.; Cho, K. Y.; Kim, D.-H. J. Ind. Eng. Chem. (Amsterdam, Neth.) 2017, 56, 196-202. doi:10.1016/j.jiec.2017.07.012

9. Patil, P. S. Mater. Chem. Phys. 1999, 59, 185-198. doi:10.1016/s0254-0584(99)00049-8

10. Kriisa, M.; Krunks, M.; Oja Acik, I.; Kärber, E.; Mikli, V. Mater. Sci. Semicond. Process. 2015, 40, 867-872. doi:10.1016/j.mssp.2015.07.049

11. Rajpure, K. Y.; Bhosale, C. H. Mater. Chem. Phys. 2002, 73, 6-12. doi:10.1016/s0254-0584(01)00350-9

12. Kärber, E.; Katerski, A.; Oja Acik, I.; Mere, A.; Mikli, V.; Krunks, M. Beilstein J. Nanotechnol. 2016, 7, 1662-1673. doi:10.3762/bjnano.7.158

13. Kim, D.-H.; Lee, S.-J.; Park, M. S.; Kang, J.-K.; Heo, J. H.; Im, S. H.; Sung, S.-J. Nanoscale 2014, 6, 14549-14554. doi:10.1039/c4nr04148h

14. Madarász, J.; Pokol, G. J. Therm. Anal. Calorim. 2007, 88, 329-336. doi:10.1007/s10973-006-8058-4

15. Timchenko, V. P.; Novozhilov, A. L.; Slepysheva, O. A. Russ. J. Gen. Chem. 2004, 74, 1046-1050 doi:10.1023/b:rugc.0000045862.69442.aa 
16. Parize, R.; Cossuet, T.; Chaix-Pluchery, O.; Roussel, H.; Appert, E.; Consonni, V. Mater. Des. 2017, 121, 1-10. doi:10.1016/j.matdes.2017.02.034

17. Chang, H.; Huang, P. J. J. Raman Spectrosc. 1998, 29, 97-102. doi:10.1002/(sici)1097-4555(199802)29:2<97::aid-jrs198>3.0.co;2-e

18. Liu, Y.; Eddie Chua, K. T.; Sum, T. C.; Gan, C. K. Phys. Chem. Chem. Phys. 2014, 16, 345-350. doi:10.1039/c3cp53879f

19. Makreski, P.; Petruševski, G.; Ugarković, S.; Jovanovski, G. Vib. Spectrosc. 2013, 68, 177-182. doi:10.1016/j.vibspec.2013.07.007

20. Ibáñez, J.; Sans, J. A.; Popescu, C.; López-Vidrier, J.; Elvira-Betanzos, J. J.; Cuenca-Gotor, V. P.; Gomis, O.; Manjón, F. J.; Rodríguez-Hernández, P.; Muñoz, A. J. Phys. Chem. C 2016, 120, 10547-10558. doi:10.1021/acs.jpcc.6b01276

21. Kharbish, S.; Libowitzky, E.; Beran, A. Eur. J. Mineral. 2009, 21, 325-333. doi:10.1127/0935-1221/2009/0021-1914

22. Medles, M.; Benramdane, N.; Bouzidi, A.; Sahraoui, K.; Miloua, R.; Desfeux, R.; Mathieu, C. J. Optoelectron. Adv. Mater. 2014, 16, 726-731.

https://joam.inoe.ro/index.php?option=magazine \&op=view\&idu=3498\& catid $=84$

23. Nakamoto, K. Infrared and Raman Spectra of Inorganic and Coordination Compounds, 6th ed.; Wiley-Blackwell: São Paulo, Brazil, 2008. doi: $10.1002 / 9780470405888$

24. Hofmann, W. Z. Kristallogr. 1933, 86, 225-245. doi:10.1524/zkri.1933.86.1.225

25. Petzelt, J.; Grigas, J. Ferroelectrics 1973, 5, 59-68. doi:10.1080/00150197308235780

26. Grovenor, C. R. M. J. Phys. C: Solid State Phys. 1985, 18, 4079-4119. doi:10.1088/0022-3719/18/21/008

27. Escorcia-García, J.; Becerra, D.; Nair, M. T. S.; Nair, P. K. Thin Solid Films 2014, 569, 28-34. doi:10.1016/j.tsf.2014.08.024

28. Boughalmi, R.; Boukhachem, A.; Kahlaoui, M.; Maghraoui, H.; Amlouk, M. Mater. Sci. Semicond. Process. 2014, 26, 593-602. doi:10.1016/j.mssp.2014.05.059

29. Birkholz, M.; Selle, B.; Fuhs, W.; Christiansen, S.; Strunk, H. P.; Reich, R. Phys. Rev. B 2001, 64, 085402. doi:10.1103/physrevb.64.085402

30. Greenwood, N. N.; Earnshaw, A. Chemistry of the Elements, 2nd ed.; Butterworth-Heinemann: Oxford, United Kingdom, 1997. doi:10.1016/c2009-0-30414-6

31. Fujishima, A.; Zhang, X.; Tryk, D. A. Surf. Sci. Rep. 2008, 63, 515-582. doi:10.1016/j.surfrep.2008.10.001

32. Madarász, J.; Krunks, M.; Niinistö, L.; Pokol, G. J. Therm. Anal. Calorim. 2015, 120, 189-199. doi:10.1007/s10973-015-4481-8

33. Madarász, J.; Krunks, M.; Niinistö, L.; Pokol, G. J. Therm. Anal. Calorim. 2004, 78, 679-686. doi:10.1023/b:jtan.0000046127.69336.90

34. Polivtseva, S.; Oja Acik, I.; Krunks, M.; Tõnsuaadu, K.; Mere, A. J. Therm. Anal. Calorim. 2015, 121, 177-185. doi:10.1007/s10973-015-4580-6

35. Lan, C.; Liang, G.; Lan, H.; Peng, H.; Su, Z.; Zhang, D.; Sun, H.; Luo, J.; Fan, P. Phys. Status Solidi RRL 2018, 12, 1800025. doi:10.1002/pssr.201800025

36. Zheng, Y. C.; Yang, S.; Chen, X.; Chen, Y.; Hou, Y.; Yang, H. G. Chem. Mater. 2015, 27, 5116-5121. doi:10.1021/acs.chemmater.5b01924

37. Kushkhov, A. R.; Gaev, D. S.; Rabinovich, O. I.; Stolyarov, A. G. Crystallogr. Rep. 2013, 58, 365-369. doi:10.1134/s1063774513020132
38. Piacente, V.; Scardala, P.; Ferro, D. J. Alloys Compd. 1992, 178, 101-115. doi:10.1016/0925-8388(92)90251-4

39. Lide, D. R., Ed. CRC Handbook of Chemistry and Physics, 87th ed.; CRC Press: Boca Raton, FL, U.S.A., 2006.

40. Ozturk, I. I.; Kourkoumelis, N.; Hadjikakou, S. K.; Manos, M. J.; Tasiopoulos, A. J.; Butler, I. S.; Balzarini, J.; Hadjiliadis, N. J. Coord. Chem. 2011, 64, 3859-3871. doi:10.1080/00958972.2011.633603

41. Rohrer, G. S. Metall. Mater. Trans. A 2010, 41, 1063-1100. doi:10.1007/s11661-010-0215-5

42. Volmer, M.; Weber, A. Z. Phys. Chem., Stoechiom. Verwandtschafts/ 1926, 119, 277-301. doi:10.1515/zpch-1926-11927

43. Abraham, D. B.; Newman, C. M. EPL 2009, 86, 16002-16007. doi:10.1209/0295-5075/86/16002

44. Ostwald, W. The Principles of Inorganic Chemistry, 2nd ed.; Macmillan and Co., Ltd.: London, United Kingdom, 1904.

45. Brookins, D. G. Econ. Geol. 1972, 67, 369-372. doi:10.2113/gsecongeo.67.3.369

46. Clouet, E. Modeling of Nucleation Processes. In ASM Handbook, Fundamentals of Modeling for Metals Processing; Furrer, D. U.; Semiatin, S. L., Eds.; ASM International: Materials Park, OH, U.S.A., 2009; Vol. 22A, pp 203-219.

47. Lokhande, C. D.; Sankapal, B. R.; Mane, R. S.; Pathan, H. M.; Muller, M.; Giersig, M.; Ganesan, V. Appl. Surf. Sci. 2002, 193, 1-10. doi:10.1016/s0169-4332(01)00819-4

48. Krishnan, B.; Arato, A.; Cardenas, E.; Roy, T. K. D.; Castillo, G. A. Appl. Surf. Sci. 2008, 254, 3200-3206. doi:10.1016/j.apsusc.2007.10.098

49. Zhu, G.; Huang, X.; Hojamberdiev, M.; Liu, P.; Liu, Y.; Tan, G.; Zhou, J.-p. J. Mater. Sci. 2011, 46, 700-706. doi:10.1007/s10853-010-4797-5

50. Bessegato, G. G.; Cardoso, J. C.; Silva, B. F. d.; Zanoni, M. V. B. J. Photochem. Photobiol., A 2014, 276, 96-103. doi:10.1016/j.jphotochem.2013.12.001

51. Zheng, L.; Jiang, K.; Huang, J.; Zhang, Y.; Bao, B.; Zhou, X.; Wang, H.; Guan, B.; Yang, L. M.; Song, Y. J. Mater. Chem. A 2017, 5, 4791-4796. doi:10.1039/c7ta00291b

52. Wang, W.; Strössner, F.; Zimmermann, E.; Schmidt-Mende, L. Sol. Energy Mater. Sol. Cells 2017, 172, 335-340. doi:10.1016/j.solmat.2017.07.046

53. Kozytskiy, A. V.; Stroyuk, O. L.; Skoryk, M. A.; Dzhagan, V. M.; Kuchmiy, S. Y.; Zahn, D. R. T. J. Photochem. Photobiol., A 2015, 303-304, 8-16. doi:10.1016/j.jphotochem.2015.02.005

54. Kamruzzaman, M.; Chaoping, L.; Yishu, F.; Farid UI Islam, A. K. M.; Zapien, J. A. RSC Adv. 2016, 6, 99282-99290. doi:10.1039/c6ra20378g

55. Morteani, G.; Ruggieri, G.; Möller, P.; Preinfalk, C. Miner. Deposita 2011, 46, 197-210. doi:10.1007/s00126-010-0316-5

56. Oja Acik, I.; Junolainen, A.; Mikli, V.; Danilson, M.; Krunks, M. Appl. Surf. Sci. 2009, 256, 1391-1394. doi:10.1016/j.apsusc.2009.08.101

57. Tauc, J.; Grigorovici, R.; Vancu, A. Phys. Status Solidi 1966, 15, 627-637. doi:10.1002/pssb.19660150224

58. Grozdanov, I. Semicond. Sci. Technol. 1994, 9, 1234-1241. doi:10.1088/0268-1242/9/6/013

59. Grozdanov, I.; Ristov, M.; Sinadinovski, G.; Mitreski, M. J. Non-Cryst. Solids 1994, 175, 77-83. doi:10.1016/0022-3093(94)90317-4 
60. Medina-Montes, M. I.; Montiel-González, Z.; Paraguay-Delgado, F.; Mathews, N. R.; Mathew, X. J. Mater. Sci.: Mater. Electron. 2016, 27, 9710-9719. doi:10.1007/s10854-016-5033-0

61. Wojdyr, M. J. Appl. Crystallogr. 2010, 43, 1126-1128. doi:10.1107/s0021889810030499

\section{License and Terms}

This is an Open Access article under the terms of the Creative Commons Attribution License

(http://creativecommons.org/licenses/by/4.0). Please note that the reuse, redistribution and reproduction in particular requires that the authors and source are credited.

The license is subject to the Beilstein Journal of Nanotechnology terms and conditions:

(https://www.beilstein-journals.org/bjnano)

The definitive version of this article is the electronic one which can be found at:

doi:10.3762/bjnano.10.18 